\title{
The Ghost of Maurice at the Court of Heraclius
}

\author{
Phil Booth / Oxford
}

\section{$\underline{\text { Introduction }}$}

In July 629, the Roman emperor Heraclius met the Persian spahbad Shahrbaraz in Cappadocia to negotiate a peace - an end to that grand war which had raged since 603, and which had witnessed, in short succession, such spectacular events as the Persian sack of Jerusalem (614), the Persian-Avar siege of Constantinople (626), and a Roman alliance with the western Gök Turks (627). ${ }^{1}$ Historians of these dramatic decades have often celebrated the role of Heraclius in reversing Roman fortunes, pointing to the unprecedented campaigns which the emperor led within the Transcaucasus in the period 622-628, and the subsequent collapse of Khusrau's regime, and his assassination, as enemies drew ever closer to Ctesiphon. ${ }^{2}$ But in 628, the Roman triumph was far from a fait accompli. For despite the succession of a more subservient shahanshah within the Persian capital, Rome's former eastern provinces-in particular its most precious resource, Egypt—remained under Persian occupation, with the formidable figure of Shahrbaraz still ensconced at Alexandria. ${ }^{3}$

It seems that at some point in or soon after 626, Shahrbaraz had become estranged from the Sasanian regime at Ctesiphon. Although the sources disagree as to whether he or Heraclius was the sponsor of the rendezvous, ${ }^{4}$ in June 629 Shahrbaraz abandoned Alexandria and made for Cappadocia. ${ }^{5}$ The details of the subsequent peace with Heraclius are not recorded but can be surmised from subsequent events: Shahrbaraz, for his part, would withdraw from former Roman territories and return various relics (the Cross, the Sponge, and the Lance) removed from Jerusalem after the Persian assault in $614 ;^{6}$ while the emperor, for his, would support Shahrbaraz's march on the Persian capital, and his establishment as regent to the infant Ardashir. ${ }^{7}$ The agreement was soon celebrated with three significant acts: first, the elevation of Shahrbaraz's son Nicetas, a Christian, to the status of patrikios; ${ }^{8}$

\footnotetext{
${ }^{1}$ For the meeting: Anonymous Chronicle to 724 ed. E.W. Brooks in Chronica minora II, CSCO 3, SS 3 (Paris, 1960) 75-156, at 147.

${ }^{2}$ See esp. the masterful contributions of James Howard-Johnston, gathered in his East Rome, Sasanian Persia and the End of Antiquity: Historiographical and Historical Studies (Aldershot, 2006); and B. Flusin, Saint Anastase le Perse et l'histoire de la Palestine au début du VIIe siècle (2 vols, Paris, 1992).

${ }^{3}$ Shahrbaraz at Alexandria: Ps.-Sebēos, History 40 ed. G. Abgaryan, Patmut 'iwn Sebēosi (Erevan, 1979$) 129$.

${ }^{4}$ For the sources and their problems see P. Booth, Crisis of Empire: Doctrine and Dissent at the End of Late Antiquity (Berkeley, CA, 2014) 156 n. 70. For the position of Shahrbaraz, C. Mango, 'Deux études sur Byzance et la Perse sassanide,' Travaux et Mémoires 9 (1985) 91-117, at 106-109.

5 The date is given in Anonymous Chronicle to 724 (Brooks 146).

${ }^{6}$ On the various traditions around the return of the Cross to Roman hands, see Flusin, Saint Anastase vol. 2 295297. For the Sponge and Lance see Paschal Chronicle ed. L. Dindorf, Chronicon Paschale (Bonn, 1832) 705, with H. A. Klein, 'Niketas und das wahre Kreuz: Kritische Anmerkungen zur Überlieferung des Chronicon Paschale ad annum 614,' Byzantinische Zeitschrift 94 (2001) 580-87, who makes a cogent case for moving the notice from 614 to 629 .

${ }^{7}$ For the sources see Booth, Crisis of Empire 156-157, with nn. 71-73 (although I would prefer now to place Shahrbaraz's coup after the meeting at Arabissus, and to imagine a swift campaign in Persia).

${ }^{8}$ See Nicephorus, Short History 17 ed. and trans. C. Mango, Nikephoros, Patriarch of Constantinople: Short History (Washington, D.C., 1990) 64. Nicetas is called patrikios in the Paschal Chronicle (Dindorf 705), describing 629 (as per n. 0000 above). He is perhaps the son of Shahrbaraz described as a hostage at Constantinople in the late 620s; see Anonymous Chronicle to 123498 ed. J.-B. Chabot, Chronicon anonymum ad annum Christi 1234 pertinens, CSCO 81-82, SS 36-37 (2 vols, Louvain, 1916-20) vol. 1233.
} 
second, the marriage of Shahrbaraz's daughter Nike to Heraclius's son Theodosius; ${ }^{9}$ and third, the construction of a church to Peace at the site of the conference itself. ${ }^{10}$ It was, for Heraclius, a spectacular diplomatic triumph, and the true crescendo of the Last Great War. ${ }^{11}$

The precise venue for the conference in Cappadocia has passed without comment in modern literature, but contemporaries cannot have missed the association. For the two great generals met at Arabissus Tripotamus, an otherwise obscure and remote location with one recent claim to fame - it had been the birthplace of the emperor Maurice, whose murder at the hands of the usurper Phocas had been, for his counterpart and protégé Khusrau, the ostensible casus belli. ${ }^{12}$ At the beginning of his reign, the otherwise parsimonious Maurice is said to have stoked some not insignificant resentment when he adorned Arabissus with a range of new amenities - a magnificent church, a hospice, a townhall, porticoes, basilicas, a palace, and a wall—and then to have rebuilt them following an earthquake. ${ }^{13}$ It is tempting to suppose, then, that Shahrbaraz and Heraclius met not only in a place with profound associations with Maurice; but also in a building which the murdered emperor had commissioned.

There is little chance that the choice of venue, which was no doubt inconvenient for both parties, was coincidental. But the conference in Cappadocia demonstrates that the ghost of Maurice long haunted protagonists in a war which, as we shall see, had also witnessed a protracted conflict over the meaning of the murdered emperor's death. In recent contributions, our comprehension of Heraclius's ideological programme both before and after the Last Great War has grown ever more sophisticated: in its construction, during, of an existential conflict between (Roman) Christians and (pagan) Persians; ${ }^{14}$ in its flirtation, afterwards, with cosmological and eschatological themes of restoration; ${ }^{15}$ and in its attempts, throughout, to delegitimise Phocas, whom Heraclius himself had usurped. ${ }^{16}$ No student of Phocas' reign would now accept without criticism the construction of it contained within Heraclian texts. But our appreciation of simultaneous constructions of the reign of Maurice is rather less developed, and historians continue to accept such constructions without due caution. ${ }^{17}$ When such constructions have been recognised, it has most often been suggested that Heraclian authors sanctified

\footnotetext{
${ }^{9}$ See Nicephorus, Short History 17. Cf. PLRE III Theodosius 44.

${ }^{10}$ Anonymous Chronicle to 724 (Brooks 139, 147).

${ }^{11}$ See further Mango, 'Deux études’ 109-112; Flusin, Saint Anastase vol. 2 288-291.

12 For Maurice’s origin: Evagrius Scholasticus, Ecclesiastical History 5.19 ed. J. Bidez and L. Parmentier, The Ecclesiastical History of Evagrius, with the Scholia (London, 1898) 214; implied also in Eustratius Presbyter, Life of Eutychius 1908-1910 ed. C. Laga, Eustratii Presbyteri Vita Eutychii Patriarchae Constantinopolitani (Turnhout, 1992) 61-62. Cf. Michael the Great, Chronicle 10.21 ed. J.-B. Chabot (4 vols, Paris, 1899-1910) vol. 4 379; Chronicle to 1234 76. See also D. Feissel, 'Trois notes sur l'empereur Maurice,' in Mélanges Cécile Morrisson, Travaux et Mémoires 16 (Paris, 2010) 253-272, at 253-258. Later Armenian legend would dispute these origins, but also acknowledge the claim of Arabissus; see N. Adontz, 'Les légendes de Maurice et de Constantin V, empereurs de Byzance,’ Études Armèno-byzantines (Lisbon, 1965) 125-136, esp. 127.

13 See John of Ephesus, Ecclesiastical History 3.5.22-23 ed. E.W. Brooks, Iohannis Ephesini Historiae ecclesiasticae pars tertia (2 vols, Louvain, 1952) vol. 1 273-275. John does not give a date for the earthquake but cf. the derivative passage in Michael the Great, Chronicle (Chabot vol. 4 379), which places it in AG 898 (= 586/7), and also reports a further, undated, earthquake at Arabissus.

${ }^{14}$ E.g. Y. Stoyanov, Defenders and Enemies of the True Cross: The Sasanian Conquest of Jerusalem in 614 and Byzantine Ideology of Anti-Persian Warfare (Vienna, 2011) esp. 45-75.

${ }^{15}$ E.g. H. J. W. Drijvers, 'Heraclius and the Restitutio Crucis: Notes on Symbolism and Ideology,' in G. J. Reinink and B. H. Stolte (eds), The Reign of Heraclius (610-641): Crisis and Confrontation (Louvain, 2002) 175-90.

${ }^{16}$ E.g. M. Meier, 'Kaiser Phokas (602-610) als Erinnerungsproblem,' Byzantinische Zeitschrift 107 (2014) 139174.

${ }^{17}$ For a recent example: R. Pfeilschifter, Der Kaiser und Konstantinopel: Kommunikation und Konfliktaustrag in einer spätantiken Metropole (Berlin, 2013) 252-293, esp. 261 with n. 21.
} 
Maurice in order to create a foil for Phocas, and thus to legitimise the latter's usurpation. ${ }^{18}$ But I will argue here that the portrait of Maurice which the emperor and his entourage promoted was far more complex and kaleidoscopic. ${ }^{19}$ On the one hand, Maurice is the master statesman, who has re-established peace between the Roman and the Persian empires; and he is the quasi-saint, who repents his sins and meets his death with stoical acceptance. On the other, however, he is also the failed ruler, who has called down his terrible fate through fracturing his covenant with God and his people; and he is the failed dynast, who has surrendered his right to establish a son as successor. Through this ambiguous image-which finds its finest expression in a narrative of Maurice's reign completed at the end of the Last Great War-the Constantinopolitan court represented Maurice not as a saint but as a failed forerunner of Heraclius, an emperor who had aspired to, but fallen from, the same principles of pious Christian rule, filial succession, and international cooperation so trumpeted in the contemporaneous peace at Arabissus. The true foil for Maurice, therefore, was not Phocas; it was Heraclius.

\section{Born in the Purple}

The reign of Maurice had begun full of promise. On 4.viii.583, a son was born to the new emperor and his wife Constantia, daughter of the emperor Tiberius. ${ }^{20}$ The event was a cause for ebullient celebration. The circus factions, we are told, competed to name the child, the Blues calling for 'Justinian' (after Justinian I, a Blue), and the Greens for Theodosius (after Theodosius II, a Green). ${ }^{21}$ The name 'Theodosius' prevailed. According to John of Ephesus, the name was indeed chosen in imitation of Theodosius II, not however for his preference in the circus, but rather for the fact that he had been the last son born in the purple. ${ }^{22}$ For almost two centuries no son had succeeded his father upon the throne of the Romans - since, in fact, the emperors had adopted Chalcedon, as some of its opponents were wont to point out. ${ }^{23}$ But now that curse had, it seemed, been lifted. Soon after the birth, at some point between September 583 and August 584, an acclamation painted on the walls of the tepidarium within the Hadrianic Baths at Aphrodisias sums up the reaction of at least some provincials: 'The fortune of the emperor triumphs! The fortune of the empress triumphs! Many years for the new Theodosius!'24

\footnotetext{
${ }^{18}$ See e.g. D. Olster, The Politics of Usurpation in the Seventh Century: Rhetoric and Revolution in Byzantium (Amsterdam, 1993) 1-2.

${ }^{19}$ For aspects of this ambiguous portrait (which I here expand and attempt to place in context) see the excellent S. Efthymiadis, 'A Historian and His Tragic Hero: A Literary Reading of Theophylact Simocatta's Ecumencial History,' R. J. Macrides (ed.), History as Literature in Byzantium (Farnham, 2010) 169-186, who moves towards reading the text as a complex 'mirror of princes' for Heraclius (cf. also Meier, 'Kaiser Phokas' 164-165)

${ }^{20}$ For the date: John of Ephesus, Ecclesiastical History 3.5.14. Same date in Michael the Great, Chronicle 10.21 (Chabot vol. 4 378); cf. Bar Hebraeus, Chronicle ed. E. W. Budge, The Chronography of Gregory Abû'l Faraj (2 vols, Oxford, 1932) vol. 2 90, giving Maurice 1. This date is preferable to that in Theophanes, Chronographia AM 6077 and 6082 which suggests he was born in late 585.

${ }^{21}$ See the scholion in Vat. Gr. $977 \mathrm{f} .184 \mathrm{v}$ and $152 \mathrm{f} .141 \mathrm{r}$., published in Y. Janssens, 'Les Bleus et les Verts sous Maurice, Phocas et Héraclius', Byzantion 11 (1936) 499-536, at 500. Feissel, 'Trois notes' 264-265 sees in the proposal of 'Justinian' an act of conciliation towards the Justinianic line represented in Germanus, Maurice’s rival and Theodosius's future father-in-law; cf. below n. 0000.

${ }^{22}$ John of Ephesus, Ecclesiastical History 3.5.14.

${ }^{23}$ See Severus of Antioch, Letters 55 ed. E. W. Brooks, A Collection of Letters from Severus of Antioch, from Numerous Syriac Manuscripts. Letters I to LXI, Patrologia Orientalis 12 (Paris, 1919) 334; repeated in John of Nikiu, Chronicle 116, 121, ed. H. Zotenberg, Chronique de Jean, évêque de Nikiou (Paris, 1883) 204-205.

${ }^{24}$ Ed. C. Roueché, Aphrodisias in Late Antiquity (London, 1989) no. 61.i, with G. Dagron, 'Nés dans la poupre,' Travaux et Mémoires 12 (1994) 105-142, at 111. Feissel, 'Trois notes’ 265-266 convincingly reconstructs a second indiction in another of the three medallions in which the acclamation also features.
} 
Theodosius was soon baptised with great pomp at Constantinople, a first step towards his integration within the wider rhythms of Roman liturgical life. It is possible that no less a figure than the future Roman pope was his godfather, for Gregory of Tours informs us that Gregory the Great, upon his election, wrote a letter of refusal 'to the emperor Maurice, whose son he had taken from the holy font (cuius filium ex lavacro sancto suspicerat)'.${ }^{25}$ Since Gregory left his role of papal apocrisiarius in the capital at some point between October 584 and December $587,{ }^{26}$ this son is perhaps to be identified with Theodosius, rather than a younger brother, ${ }^{27}$ although Gregory of Tours is our only source for the claim. ${ }^{28}$ The date of the baptism is uncertain, but it has been suggested that it occurred at Epiphany $\left(6^{\text {th }}\right.$ January) 584, and that a medallion now held at Dumbarton Oaks commemorates the occasion. On the obverse this medallion has an enthroned Virgin and child and an elaborate Nativity scene (and the inscription, 'Christ, our God, help us'); while the reverse depicts the Baptism of Christ, with the inscription, 'This is my son, with whom I am well-pleased' (Matt. 3:17). ${ }^{29}$ The medallion once belonged to a larger treasure discovered near Kyrenia on Cyprus in c.1900, which contained numerous gold and silver objects of Constantinopolitan provenance. This treasure included a famous gold girdle, now in the Metropolitan Museum, and comprised of solidi of Theodosius II, Justin/Justinian, and Maurice. It also integrates some remarkable consular medallions of Maurice, in all likelihood produced for his first consulship (which began on 25.xii.583). ${ }^{30}$ Close technical and stylistic similarities between the consular medallions and that depicting Christ's baptism suggest that both were produced within the imperial mint at around the same time. An obvious context for the Dumbarton Oaks medallion-with its scenes of birth and baptism, and its paternal inscription from Matthew-would be the baptism of Theodosius. ${ }^{31}$

For contemporaries, Theodosius's birth meant more than the silencing of anti-Chalcedonian polemicists. For now, John of Ephesus reports, the imperial aspirations of ambitious but undeserving

\footnotetext{
${ }^{25}$ Gregory of Tours, History of the Franks 10.1 ed. B. Krusch and W. Levison, Scriptores Rerum Merovingicarum 1.1: Gregorii Episcopi Turonensis Libri Historiarum X (Hanover, 1951) 478.

${ }^{26}$ Terminus ante quem and terminus post quem provided in P. Ewald and L. M. Hartmann, Gregorii I papae Registrum epistolarum Tomus II, MGH Epistolae 2 (Berlin, 1899) 437-439 (a donation of Gregory to his own Monastery of St Andrew, dated 28.xii.587); 440-1 (a letter from Pelagius II to Gregory in Constantinople, dated 5.x.584). See also P. Meyvaert, 'A Letter of Pelagius II Composed by Gregory the Great,' in J. C. Cavadini (ed.), Gregory the Great: A Symposium (Notre Dame, IN, 1995) 94-116.

${ }^{27}$ The Paschal Chronicle (Dindorf 693-694) names five sons besides the eldest Theodosius; see below n. 0000, but their precise dates of birth are not known.

${ }^{28}$ The idea is nevertheless embedded in modern literature; see e.g. M. Whitby, The Emperor Maurice and His Historian: Theophylact Simocatta on Persian and Balkan Warfare (Oxford, 1988) 18. There is good reason, however, to be cautious. Despite his rich correspondence with Maurice's court, Gregory nowhere explicitly mentions Theodosius or another imperial child, and later welcomed Phocas' coup in strikingly effusive terms; see Letters 13.32 ed. D. Norberg, S. Gregorii Magni Registrum Epistularum Libri I-VII, CCSL 140, 140a (2 vols, Turnhout, 1982) 1033-1034. An independent Latin narrative, moreover, reports that Gregory placed an official icon of Phocas and Leontia in the Lateran, at the time when 'Maurice was killed along with all his male children, that is, Theodosius the already crowned (Theodosio iam coronato), Tiberius, Peter, Paul, and Justinian ...' (Appendix VIII in ibid. vol. 2 1101). The same text also reports the death of Maurice's brother Peter, Constantine Lardys, and the imperial notarios George. The list is not dissimilar to that in Paschal Chronicle (Dindorf 694), which has Theodosius, Peter, Justin, and Justinian, omitting Paul (but cf. ibid. 693) and has the patrician and magister militum Comentiolus in place of George; cf. below 0000. Both perhaps draw from an official notice, with the sons listed in chronological order (so Feissel, 'Trois notes' 266).

${ }^{29}$ See M. C. Ross, 'A Byzantine Gold Medallion at Dumbarton Oaks,' Dumbarton Oaks Papers 11 (1957) 247261.

${ }^{30}$ Consular medallions: P. Grierson, 'The Kyrenia Girdle of Byzantine Medallions and Solidi,' Numismatic Chronicle 15 (1955) 55-70. First consulship: Theophanes, Chronographia AM 6076; cf. Paschal Chronicle (Dindorf 691).

${ }^{31}$ See P. Grierson, 'The Date of the Dumbarton Oaks Epiphany Medallion,' Dumbarton Oaks Papers 15 (1961) 221-224.
} 
men were curtailed, and members of the elite instead competed to surpass each other's gifts for the infant. ${ }^{32}$ For some observers, therefore, Theodosius's birth promised a period of peace for the empire. So it was that in 593/4 Evagrius Scholasticus-who seems to have composed an encomium on Theodosius's birth, and to have received the dignity of prefect as a result-ended his entire, six-book Ecclesiastical History with the concluding sentiment that, for Maurice, that birth provided 'a foretaste of every happiness for him and for the state. ${ }^{33}$

While still a child Theodosius was co-opted into the imperial college. By 587 he had been proclaimed Caesar, ${ }^{34}$ and at Easter in 590 (the $26^{\text {th }}$ March) he was elevated to the rank of Augustus. ${ }^{35}$ Our best source for that event, the Paschal Chronicle, continues to note that it 'was not posted in the records, and none of the other actions of imperial recognition was performed in his case, except only the coronation. ${ }^{36}$ That the new emperor 'was not posted in the records' means Theodosius's absence from official regnal formulae, for he does not appear in those produced within the Paschal Chronicle, ${ }^{37}$ in diplomatic letters from the capital, ${ }^{38}$ and in contemporaneous documents from Egypt, Palestine, and Italy. ${ }^{39}$ Nevertheless, some contemporaries could still regard him as co-emperor proper: thus a Cilician inscription of 596, dedicating a church, proclaims Theodosius as emperor alongside his father ( $\dot{\varepsilon} \pi \grave{\tau} \tau \tilde{\omega} v$

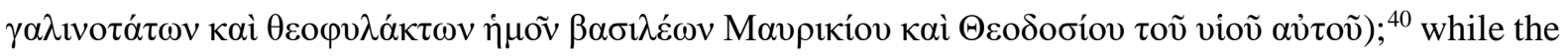
acta of a Roman council of 5.vii.595 (Maurice 13, indiction 13) have the incipit, Regnante in perpetuum Domino nostro Iesu Christo, temporibus piissimi ac serenissimi domini Mauricii Tiberii et Theodosii Augustorum ... (but note that Theodosius is here denied the title dominus). ${ }^{41}$

It is evident that Theodosius assumed a central role in the regime's official propaganda. He is, as we might expect, absent from almost all of Maurice's gold coins. But there survives in a single example, a spectacular solidus on which he features. This bears on the obverse a bust of a beardless, cuirassed man with a plumed helmet and globus cruciger. Above his head is the inscription DNTEODO-

\footnotetext{
32 John of Ephesus, Ecclesiastical History 3.5.14.

${ }^{33}$ Evagrius Scholasticus, Ecclesiastical History 6.24: 'Maurice Tiberius sent me prefectural diptychs for what we composed at the time when he freed the empire from the disgrace and brought Theodosius into the light, providing a foretaste of every happiness for himself and for the state.' Trans. M. Whitby, The Ecclesiastical History of Evagrius Scholasticus (Liverpool, 2000) 317.

${ }^{34}$ John of Biclar, Chronicle ed. T. Mommsen, Chronica minora saec. IV. V. VI. VII Vol. II, MGH 11 (Berlin, 1894) 211-220, at 217 (under Maurice 5): Mauricius Theodosium filium suum ex filia Tiberi imperatoris natum Caesarem facit.

${ }^{35}$ Paschal Chronicle (Dindorf 691); cf. Theophanes, Chronographia AM 6082. John of Biclar, Chronicle (Mommsen 218) places the same event in Maurice 6 (=587/8). A date between 586 and 592 is implied in Michael the Great, Chronicle 10.23 (assuming the patriarchal coronation described is as Augustus).

${ }^{36}$ Paschal Chronicle (Dindorf 691).

${ }^{37}$ Paschal Chronicle (Dindorf 691-693); cf. the entries on Heraclius Constantine at ibid. (Dindorf 704-727).

${ }^{38}$ See the letter of 591 from Maurice to Gregory the Great ed. P. Ewald and L. M. Hartmann, Gregorii I papae Registrum epistolarum Tomus I, MGH Epistolae 1 (Berlin, 1891) 21-23 (as 16b), at 22. Cf. also the petition of the bishops of Raetia Secunda in 591 to Maurice ed. E. Schwartz, Concilium universale Constantinopolitanum sub Iustiniano habitum II, ACO, ser. 1, tom. 4, vol 2 (Berlin, 1914) 132-135, at 132.

${ }^{39}$ For Maurice's (complex) regnal and consular/post-consular formulae in Egypt see R. S. Bagnall and K. A. Worp, 'Chronological Notes on Byzantine Documents VIII,' Bulletin of American Society of Papyrologists 18 (1981) 33-54, at 33-38; J. R. Rea in P.Oxy. LVIII 51-57; and then R. S. Bagnall and K. A. Worp, Chronological Systems of Byzantine Egypt ( $2^{\text {nd }}$ ed., Leiden, 2004) 50-52, 260-265. For examples from elsewhere, with Theodosius also absent: P.Ness. III 29 (Elusa, 590); P.Ness. III 30 (Nessana, 596); P.Ital. II 37 = P.Marini 122 (Ravenna, 591).

${ }^{40}$ See I.Cilicie no. 118 = SEG 37, no. 1261 (ind. 14). Cf. Theodosius's absence in the (now lost) funerary inscription from Albenga (dated 13.iv.597) in Supplementua italica 4 (Rome, 1981-) vol. 4277 no. 32 = AÉp 1937 no. 219.

${ }^{41}$ Ed. Ewald and Hartmann, Gregorii I papae Registrum 362-367 (as 5.57a), at 362.
} 
SIUSPPANA. On the obverse is a standing angel, holding a long staff mounted with a chi-rho in one hand, and a globus cruciger in the other. Above the angel is the inscription VICTORI-AAUGGA. ${ }^{42}$ The coin is almost identical to a solidus of Maurice produced at Carthage, for which the final letters of the inscriptions have been shown to be (for the period from 582/3-596/7, when the two coincide) the regnal year and indiction; and, thereafter, the indiction alone. ${ }^{43}$ We can therefore read our obverse inscription as $\mathrm{D}$ (ominus) $\mathrm{N}$ (oster) TEODOSIUS $\mathrm{P}$ (ater) $\mathrm{P}$ (atriae) $\mathrm{AN}(\mathrm{no}) \mathrm{A}$; and the reverse as VICTORIA AUG(ustorum) A. Thus we have indiction 1 on the reverse (582/3, 597/8, 612/3), and either regnal year 1 or indiction 1 on the obverse. It is tempting to associate the coin, which must also come from Carthage, with Theodosius's birth, and to consider it as a special issue designed to celebrate that event. But in this case it would have to belong to the brief period 4-31.viii.583-that is, between Theodosius's birth and the end of the first indiction-and we are left with the inconvenient facts that Theodosius is not depicted as an infant or child, and is described both as dominus and (co-)augustus. This seems impossible, and our sole option is to conclude that the coin was produced in 597/8, and that the terminal letters of both inscriptions refer to the indiction.

Although Theodosius is otherwise absent from Maurice's gold coinage, his importance to ideological projections of the regime is demonstrated through his appearance on some special silver and bronze issues of provincial mints. A series of silver coins produced, like our solidus, at Carthage present him, beardless, with cuirass and either a crown or plumed helmet - the inscription above reads $\mathrm{D}$ (ominus) $\mathrm{N}$ (oster) TEODOSIUS $\mathrm{P}$ (ater) $\mathrm{P}$ (atriae) A(ugustus). The reverse of one type bears the simple pious inscription 'AMENITAS DEI'; while on another the reverse bears a cross and two crowned figures, male and female, who must be Maurice and Constantina. ${ }^{44}$ The three also appear together on a follis and half-follis of the Cherson mint. These presented, on the obverse, two standing figurescrowned and in imperial dress - who must again be Maurice and Constantina; and, on the reverse, an image of a smaller standing figure, no doubt their eldest son. ${ }^{45}$ Although the precise date of these silver and bronze coins is not clear, the presence of Theodosius's parents, and the dating of the aforementioned solidus to 597/8, both encourage a date before the death of Maurice in November 602 .

We can assume, then, that when in 590 the Merovingian king Childebert II-in a letter concerning the return to his protection of a nephew in Constantinople-petitioned Theodosius himself to intercede with his father 'until you yourself happily succeed to the rule (donec vos ipsi feliciter succedatis in regnum)', he was not only flattering his recipient but expressing an expectation which stretched well beyond the empire's borders. ${ }^{46}$ Contemporaries cannot have doubted that Maurice would establish a son as successor - for even if Theodosius were to die before his father, there were five other sons (as well as three, perhaps four, daughters) to take his place as heir. ${ }^{47}$ But we should remember that the principle of filial succession had been dormant for two centuries and, although no doubt accepted as legitimate and even celebrated, could never exclude those diverse other routes through which a

\footnotetext{
42 SB 141 no. 613 = H. J. Berk, Roman Gold Coins of the Medieval World 393-1453 (London, 1986) no. 95.

43 See P. Grierson, 'Dated Solidi of Maurice, Phocas, and Heraclius,' Numismatic Chronicle 10 (1950) 49-70, at 51-57, 63-66. For examples: DOC vol. 1 353-355 nos 215-233; BNC vol. 1 200-202; MIB vol. 2 Mauricius nos 24-26; SB 130 no. 547-549.

${ }^{44}$ See e.g. BMCByz vol. 1 159-160 nos 293-295; DOC vol. 1376 nos 305-308; BNC vol. 1 203-204; MIB vol. 2 Mauricius nos. 59-62; SB 140 nos 614-615.

45 See e.g. BMCByz vol. 1 158-159, nos 289-292; DOC vol.1 373-375 nos 297-303; BNC vol. 1 214-215; MIB vol. 2 Mauricius nos 157-162; SB 137-139 nos 603-611.

${ }^{46}$ Epistolae Austrasiacae 43 (Gundlach 149).

${ }^{47}$ For the sons see above n. 0000, and for the daughters below n. 0000. Maurice's reproductive prowess was even ribbed in popular song; see Ps.-John of Antioch, Chronicle 317 (= De ins. 107) ed. U. Roberto, Ioannis Antiocheni fragmenta ex historia chronica (Berlin, 2005) 317; Theophanes, Chronographia 6093.
} 
private individual could accede to, or claim, the throne. The succession of Theodosius, therefore, could not be assumed, but was instead in need of constant reaffirmation via a complex set of rituals and representations through which he was ingratiated as the son not of the emperor, but rather of the empire at large. ${ }^{48}$

\section{The Supplicant Son}

It is perhaps not coincidental that Theodosius's elevation to the rank of Augustus, at Easter 590, occurred as news of a significant rebellion against the Persian ruling house first began to filter across the eastern frontier. Since his accession, Maurice had presided over a series of inconclusive tit-for-tat exchanges along the border, but in late 589 the Sasanian regime was thrown into chaos when the general Bahram Shubin rebelled against the shahanshah Hormizd IV. Let us remind ourselves of the outline of events, as reported in Roman sources. ${ }^{49}$ Following the rebellion, but before the Bahram reached the capital, Hormizd was deposed and blinded, and his son, Khusrau II, elevated in his stead. ${ }^{50}$ Bahram, however, refused to recognise the succession, and soon defeated Khusrau's forces near Ctesiphon, forcing the new shahanshah into flight. ${ }^{51}$ Khusrau now travelled along the Euphrates and-along with an entourage of wives, two infants, and some noblemen - arrived at, and was admitted to, the Roman fortress at Circesium. ${ }^{52}$ From here, he dispatched a letter to Maurice in which appealed to the principle of Rome and Persia as the two eyes of the earth, presented Bahram as the agent of demonic disorder, and called upon the emperor to intervene, calling himself his son and supplicant. ${ }^{53}$ Soon after he took refuge at Hierapolis and, with Maurice demurring into the summer, sent ambassadors to the capital offering to the emperor and senate eternal peace and the return of former Roman possessions:

\footnotetext{
${ }^{48}$ Cf. G. Dagron, Empereur et prêtre: Étude sur le “césaropapisme” byzantine (Paris, 1996) 33-73.

${ }^{49}$ The following account of Khusrau's deposition and flight to Roman territories is based in particular on Theophylact, History 4.1-14 ed. C. de Boor and P. Wirth, Theophylacti Simocattae historiae (Stuttgart, 1972) 149-181; and also Evagrius Scholasticus, Ecclesiastical History 6.15-18. Both authors depend here on the lost History of John of Epiphania, of which a single fragment survives (ed. L. Dindorf, Historici graceci minoores I [Leipzig, 1870] 375-382) and which seems to have culminated in Khusrau's flight and restoration; see T. Olajos, Les sources de Théophylacte Simocatta historien (Leiden, 1988) 14-66.

${ }^{50}$ For the date (27.vi.590) see S. Tyler-Smith, 'Calendars and Coronations: The Literary and Numismatic Evidence for the Accession of Khusrau II,’ Byzantine and Modern Greek Studies 28 (2004) 33-65.

${ }^{51}$ Cf. for these events Theophanes, Chronographia AM 6080 (for the most part dependent on Theophylact); Chronicle to 1234 80; Michael the Great, Chronicle 10.23; Agapius, Universal History ed. A.A. Vasiliev, Kitab al-'Unvan: Histoire universelle, écrite par Agapius de Menbidj Patrologia Orientalis 5.4, 7.4, 8.3, 11.1 (4 vols, Paris, 1910-1915) vol. 3 441; Eutychius of Alexandria, Annals (Alexandrian Recension) 27 (Breydy 115-116); Chronicle of Seert 58 ed. A. Scher, Histoire Nestorienne: Chronique de Séert, Patrologia Orientalis 4.3, 5.2, 7.2, 13.4 (4 vols, Paris, 1908-19) vol. 4 465-466; Ps.-Sebēos, History 10 (Abgaryan 75-76); Dīnawarī, General History ed. V. F. Girgas Kitāb al-Ahbār at-Tíwāl (Leiden, 1888) 85-91; Țabarī, ed. M. J. de Goeje et al., Annales quos scripsit Abu Djafar Mohammed ibn Djarir at-Tabari (15 vols, Leiden, 1879-1901) vol. 2 993-999. For the revolt of Bahram and its ideological context see esp. Z. Rubin, 'Nobility, Monarchy and Legitimation under the Later Sasanians,' in J. Haldon and L. Conrad (eds), The Byzantine and Islamic Near East Vol. 6: Elites Old and New (Princeton, 2004) 235-73.

${ }^{52}$ Note that according to Dionysius of Tel-Mahre (Chronicle to 1234 80-81; Michael the Great, Chronicle 10.23), before coming to Hierapolis Khusrau also came to Edessa, and was received there by a John. Upon his later reconquest of the city, he also reports in a long anecdote, Khusrau remembered an insult from John's wife at this earlier reception, and deported her to a prison in Persia (Chronicle to 1234 87; Michael the Great, Chronicle 10.25). Agapius, Universal History (Vasiliev vol. 3 442), also has the account, which therefore derives from the so-called 'eastern source', but makes Khusrau come first to Nisibis, then Edessa; cf below n. 0000. Khuzistan Chronicle 58 makes Khusrau’s route Circesium-Edessa-Hierapolis.

${ }^{53}$ In the Chronicle to 1234 81, the same letter is sent from Hierapolis. In Ṭabarī, Annals (de Goeje vol. 2 994, 999), Khusrau's appeal is made from Antioch.
} 
Martyropolis, Dara, and Armenia. ${ }^{54}$ With these dramatic concessions, peace was agreed, and formalised at meeting at Constantina between Khusrau, Domitian, bishop of Melitene (the emperor's nephew), and Gregory, patriarch of Antioch. ${ }^{55}$

Following the capitulation of Martyropolis, and the defection of the Persian force at Nisibis in late 590, Maurice dispatched a large loan of monies, a force of soldiers, and an imperial retinue to assist in the restoration. In Spring 591 Khusrau, along with the new magister militum Narses, entered into Dara-which Khusrau now recognised, in formal letter sent to Maurice, as a Roman possession-and thence the allied forces marched into Persia and, swelled with Armenian reinforcements from the north, inflicted a crushing defeat on Bahram at Ganzak. ${ }^{56}$ At this the Romans withdrew, but not before the generals had reminded Khusrau 'that he should not forget the kindness and salvation which had had received from the Romans. ${ }^{57}$ With the Sasanian line restored, Khusrau then fulfilled his remaining promises to Maurice, restoring large parts of Armenia to Roman rule. ${ }^{58}$

Sources written at some distance from events suppose that Khusrau had become a Christian, and had even been baptised at the hands of the Constantinopolitan patriarch. ${ }^{59}$ The alleged baptism belongs to the realm of legend, but Christian authors much closer to events could also suppose a secret conversion of the shahanshah. Thus, for example, our two main sources for events imagine how, upon his flight from Bahram, Khusrau failed to decide upon a destination, instead giving rein to his horse, renouncing his Zoroastrian faith and entrusting himself to God. ${ }^{60}$ It is probable, in fact, that such stories reflect the fleeing Khusrau's own propaganda, for a broader pattern suggests a deliberate effort to proffer his own conversion in discussions with the Romans. The Chronicle to 1234 informs us that, before fleeing his throne, Khusrau called upon the Jafnid Abū Jafna Nu'mān b. al-Mundhir, then at Sergiopolis, to deliver his plea to Maurice. ${ }^{61}$ This manoeuvre appears as the first manifestation of an

\footnotetext{
${ }^{54}$ For the terms and Armenian concessions see also Ps.-Sebēos, History 11 (Abgaryan 76); cf. Narratio de rebus Armeniae 94.

${ }^{55}$ Cf. Ps.-Sebēos, History 11 (Abgaryan 76), indicating some dissent in the senate, as also John of Nikiu, Chronicle 96; Agapius, History (Vasiliev vol. 3 444). For the career of Domitian: E. Honigmann, 'Two Metropolitans, Relatives of the Emperor Maurice,' in Patristic Studies, Studi e Testi (Vatican City, 1953) 217-225; PLRE III Domitianus. For Gregory of Antioch: P. Goubert, 'Patriarches d'Antioche et d'Alexandria contemporains de saint Grégoire le Grand: Notes de Prosopographie byzantine,’ Revue des études byzantines 25 (1967) 65-76.

${ }^{56}$ For these events see esp. Theophylact, History 4.14-5.10; Evagrius Scholasticus, Ecclesiastical History 6.19; Ps.-Sebēos, History 11 (Abgaryan 76-80). On the war cf. also the accounts in Theophanes, Chronographia AM 6081; Agapius, Universal History (Vasiliev vol. 3 444-446); Chronicle to 1234 81; Michael the Great, Chronicle 10.23; John of Nikiu, Chronicle 96; Khuzistan Chronicle ed. I. Guidi in Chronica minora I, CSCO 1, SS 1 (Paris, 1960) 15-39, at 15-16; Chronicle of Seert 58; Eutychius of Alexandria, Annals (Alexandrian Recension) 27 (Breydy 115-117); Dīnawarī, General History (Girgas 96-98); Țabarī, Annals (de Goeje vol. 2 999-1001). On the Armenian involvement see also Narratio de rebus Armeniae 93-95 ed. G. Garitte, La Narratio de Rebus Armeniae, CCSO 132 (Louvain, 1952) 39 (with the commentary at 225-231).

57 Theophylact, History 5.11.8 trans. M. Whitby and M. Whitby, The History of Theophylact Simocatta (Oxford, 1986) 147.

58 See Ps.-Sebēos, History 12 (Abgaryan 84).

${ }^{59}$ See the confused account in Fredegar, Chronicle 4.8 ed. J. M. Wallace-Hadrill, The Fourth Book of the Chronicle of Fredegar (London,1960) 7-11; Paul the Deacon, History of the Lombards 4.50 ed. L. Capo, Paolo Diacono: Storia dei Longobardi (Verona, 1992) 232-234. Similar rumours attached to Khusrau I; see e.g. John of Nikiu, Chronicle 95.

${ }^{60}$ Theophylact, History 4.11; Evagrius Scholasticus, Ecclesiastical History 6.17; cf. Theophanes, Chronographia AM 6080 where the horse is given free rein but God is not mentioned. A similar tale appears in the Khuzistan Chronicle (Guidi 16), in which it is stated that as Khusrau set out for war, an image of an old man appeared to him, and that his wife Shirin later identified the man as 'Sabrisho bishop of Lashum' (the future catholicos). Cf. Chronicle of Seert 65, placing the same anecdote in a later context.

${ }^{61}$ Chronicle to 123480 (vol. 1 215), although the name is perhaps a mistake for Jafna b. Nu'mān b. Mundhir. Cf. Agapius, Universal History (Vasiliev vol. 3 442), calling the Arab 'Jafna’ and without the detail about Sergiopolis;
} 
aspiration to arrive in Roman territories in the midst of Christian luminaries. Thus according to the Khuzistan Chronicle, upon his restoration Khusrau was wrath with the Nestorian catholicos Ishoyahb, for the latter, much to Maurice's disappointment, had not accompanied him in flight, nor met him upon his return march into Persia. ${ }^{62}$ The same is also said of the Nasrid Nu'man (distinct from his Jafnid namesake), a recent convert from paganism. ${ }^{63}$

Despite the evident enthusiasm of Maurice's regime at the prospect, Khusrau did not convert a letter of Gregory the Great, sent in 593, commiserates with Domitian for his failed efforts. ${ }^{64}$ Nevertheless, Khusrau's flirtation with the Christian faith was to continue even after his restoration, and the period from 591-602 is celebrated in Christian sources as a time of peace and open patronage in Persia. ${ }^{65}$ In the narrative of Theophylact Simocatta, before confronting Bahram in their final confrontation, Khusrau is said to have turned once again to the Christian God, and supplicated saint Sergius for success, promising the oblation of an elaborate gold cross. ${ }^{66}$ This again appears to present us with an echo of the shahanshah's own self-presentation, for following his restoration he indeed dedicated to Sergius an elaborate Justinianic cross which his grandfather had pillaged from Sergiopolis, ${ }^{67}$ and to which he added an extensive Greek inscription recording his earlier petition to the saint. ${ }^{68}$ Soon after he sent more gifts to the saint, inscribing a golden paten with an inscription which memorialised the saint's earlier aid, but also celebrated a new miracle through which Shirin, Khusrau's Christian wife, had conceived through the saint's intercession. ${ }^{69}$ These remarkable ex votos were perhaps the first in a series of prominent Christian artefacts which passed between the two regimes. At Maurice's request - and as part of his wider efforts to collect in his capital various Christian relicsKhusrau dispatched the relics of the prophet Daniel from Susa (before popular pressure and two reported

Michael the Great, Chronicle 10.23, where the intermediary is simply the Roman commander at Sergiopolis. There is therefore some confusion over whether the messenger was Nu'man b. Mundhir or his son Jafna, but the former at this stage seems to have been in exile; see John of Ephesus, Ecclesiastical History 3.3.42; Evagrius Scholasticus, Ecclesiastical History 6.2, with PLRE III Naamanes (al-Num‘ān ibn al-Mundhir) 3. On his apparent son Jafna see the account of the Severan colloquium of 586 in Michael the Great, Chronicle 10.22 (Chabot vol. 4 383) where he is placed first at Hierapolis, and then in a Church of St Sergius at Gabitha (the Jafnid capital). Cf. below n. 0000 and PLRE III Jafnah (Gophna); ibid. Gōphna. Note that in Dīnawarī, General History (Girgas 95), it is another apparent Jafnid, Hālid b. Jabala al-Ġassan̄, who leads Khusrau from Yarmuk to Constantinople. On Rome and the Jafnids see esp. G. Fisher, Between Empires: Arabs, Romans, and Sasanians in Late Antiquity (Oxford, 2011) with 179 on Jafna.

62 Khuzistan Chronicle (Guidi 15-16); Chronicle of Seert 42.

${ }^{63}$ Khuzistan Chronicle (Guidi 17, 19); Chronicle of Seert 50, 60, 65, 87. For Nu'man's conversion see also Evagrius Scholasticus, Ecclesiastical History 6.22, with PLRE III Naamanes (al-Nu'mān) 4, and P. Wood, 'Christianity and the Arabs in the Sixth Century,' in G. Fisher and J. Dijkstra (eds.), Inside and Out: Interactions between Rome and the Peoples on the Arabian and Egyptian Frontiers in Late Antiquity (Leuven, 2014) 353-368, at 366-367.

${ }^{64}$ Gregory the Great, Letters 3.62 (Norberg vol. 1 212): 'Even though in truth I grieve that the emperor of the Persians has not been converted, I nevertheless wholly rejoice that you have preached the Christian faith to him.' 65 See e.g. Chronicle of Seert 58, 70; Michael the Great, Chronicle 10.24; Ps.-Sebēos, History 13 (Abgaryan 85). Further discussion in Flusin, Saint Anastase vol. 2 99-106.

66 Theophylact, History 5.1.7-8; and cf. 5.2.4 (and 5.15.9-10 on a vision of the Virgin, predicting Khusrau's victories).

${ }^{67}$ Cf. Procopius, Wars 2.20.5-16 ed. H. B. Dewing, Procopius, History of the Wars, Books I-II (Cambridge, MA, 1914) 432-434; Evagrius Scholasticus, Ecclesiastical History 4.28.

${ }^{68}$ For the cross and its inscription see Evagrius Scholasticus, Ecclesiastical History 6.21; Theophylact, History 5.13.1-6 (thinking the inscription an accompanying letter).

${ }^{69}$ Evagrius Scholasticus, Ecclesiastical History 6.21; Theophylact, History 5.14 (again thinking the inscription a letter). On Khusrau's patronage of St Sergius see E. Key Fowden, The Barbarian Plain: Saint Sergius between Rome and Iran (Berkeley, CA, 1999) 134-141. On Shirin and her patronage of Persian Christians see M. Hutter, 'Shirin, Nestorianer und Monophysiten. Konigliche Kirchen- politik im spaten Sasanidenreich,' in R. Lavenant (ed.), Symposium Syriacum VII (Rome, 1998) 373-86. 
miracles led to a reversal); ${ }^{70}$ and the Roman emperor is also said to have commissioned an icon of the catholicos Sabrisho, Ishoyahb's successor, and to have requested and received his cap, which he placed amongst the palace's other relics. ${ }^{71}$ In return, Maurice dispatched to Sabrisho a encrusted gold cross, and a piece of the True Cross. ${ }^{72}$ As contacts increased across the border, both rulers used prominent Christians as ambassadors. ${ }^{73}$

This cultural exchange is indicative of a wider co-operation of the two courts. In the 590s confidence in peace along the eastern frontier allowed Maurice to move soldiers into the Balkans, ${ }^{74}$ and when trouble presented itself in Armenia, the Roman and Persian regimes could even collaborate. ${ }^{75}$ Multiple sources claim that in his initial appeal to Maurice, Khusrau had posed as the Roman emperor's son, and this filial stance seems then to have been maintained in the subsequent decade. ${ }^{76}$ It is possible, in fact, that the houses of the two emperors were now bound together through marriage, for according to a range of sources which draw on the matrix of texts which comprised, and elaborated, the Sasanian historiographical tradition (the so-called 'Book of Lords'), upon his restoration Khusrau received the hand of Maurice's daughter, Maria, in marriage. ${ }^{77}$ As a gift for his bride, it is said, Khusrau constructed two churches (one dedicated to Sergius, another to the Virgin) which no less a figure than Anastasius of Antioch, the Roman Chalcedonian patriarch, then consecrated. ${ }^{78}$ Although the existence of Maria, who does not appear in Roman sources, is difficult to substantiate, her presence within the Sasanian tradition nevertheless serves to reinforce the closeness of the two regimes, and to implicate the looming fates of the two ruling families.

70 Ps.-Sebēos, History 14 (Abgaryan 85-86); for other (unsuccessful) efforts of Maurice cf. head of St Paul (Gregory the Great, Letters 4.30); relics of Demetrius (John of Thessalonica, Miracles of Demetrius 5 ed. P. Lemerle in Les plus anciens recueils des Miracles de saint Démétrius [2 vols, Paris, 1979] vol. 1, 47-165, at 8890).

${ }^{71}$ See Chronicle of Seert 67. For Maurice's cultivation of ascetics see also the claims in Life of Theodore of Sykeon 54, 82, 97 ed. A.-J. Festugière, Vie de Théodore de Sykéon (Brussels, 1970).

${ }^{72}$ Chronicle of Seert 67, noting that Khusrau intercepted the piece on behalf of Shirin, and that Sabrisho requested a second, delivered through the bishop and ambassador Milas (ibid. 68).

${ }^{73}$ Theophylact, History 5.15.9 (on Probus of Chalcedon); Chronicle of Seert 67, 68, 78 (on Maroutha of Chalcedon [= Probus?], and Milas), 79 (on Mar Aba of Kashkar). The embassy reported by Mari, History of the Nestorian Patriarchs ed. H. Gismondi, Maris, Amri, et Salibae de patriarchis Nestorianorum commentaria (2 vols, Rome, 1896-1899) vol. 1 f.173a-b seems to confuse Ishoyahb I and II.

${ }^{74}$ See Whitby, Emperor Maurice 156-165.

75 Ps.-Sebēos, History 15-16 (Abgaryan 86-88).

${ }^{76}$ See e.g. Theophylact, History 4.10.1-3, 5.3.11; Evagrius Scholasticus, Ecclesiastical History 6.17; Theophanes, Chronographia 6081; Ps.-Sebēos, History 11 (Abgaryan 76); Chronicle to 1234 81; Michael the Great, Chronicle 10.23; Agapius, Universal History (Vasiliev vol. 3 443, 444).

${ }^{77}$ See Dīnawarī, General History (Girgas 95); Țabarī, Annals (de Goeje vol. 2 994, 999); al-Mas ‘ūdī, Fields of Gold ed. and trans. C. Barbier de Meynard and A. Pavet de Courteille, Les prairies d'or (Paris, 1874) vol. 2 221; al-Tha 'ālibī, History of the Persian Kings ed. and trans. H. Zotenberg, Histoire des rois des Perses (Paris, 1900) 668-671, 694, 712; Eutychius of Alexandria, Annals (Alexandrian Recension) 27 (Breydy 117, also 118-119); Chronicle of Seert 58, 92, where she is identified with, and then distinguished from, Shirin; Georgian Chronicles ed. S. Qauxč‘išvili, K'art'lis C‘xovreba (2 vols, Tblisi, 1955-1959) vol. 1 221; Ferdowsi, Shahnameh trans. J. Mohl, Le Livre des Rois (7 vols, Paris, 1878) vol. 7 107-111 (see also 135, 148-150, 225, 228, 237, 247). Khuzistan Chronicle 17 mentions in passing two Christian wives, Shirin and Maria, but does not call the latter the daughter of Maurice. Cf. also below n. 0000.

${ }^{78}$ See Chronicle to 123481 (Chabot vol. 1 217). Cf. Michael the Great, Chronicle 10.23, Bar Hebraeus, Chronicle (Budge vol. 2 92) in which Khusrau also builds a church to the Apostles. For the peace and the filial relationship: ibid. 10.24. Agapius, Universal History (Vasiliev vol. 3 444) describes the foundation of the same two churches as the Chronicle to 1234, but does not mention Maria. Chronicle of Seert 58 also mentions two, unnamed, churches which Khusrau built in honour of Maria. 


\section{Death on the Bosporus}

At some point in the period between 592 and 601, one Stephen, Chalcedonian bishop of Hierapolis-a probable witness to Khusrau's arrival in the Roman East-, composed in Syriac a Life of Golinduch, a female Persian aristocrat and convert who, following her arrest and miraculous release from the infamous Lethe prison, had fled to, and died within, Roman territories. There, according to the extant Georgian version of this Life, Golinduch - foreseeing the flight of the shahanshah, his return to the throne, and the imminent dissolution of the Persian empire-intercepted Khusrau and Domitian at Hierapolis, and predicted the former's successful restoration, as well as the subsequent coming of the Antichrist. ${ }^{79}$ Golinduch's tale became something of a cause celebre in the Roman world, and is repeated, with some significant variations, in a number of sources. ${ }^{80}$ There is, however, good reason to suspect that all is not as it seems. For it in fact appears that Golinduch was a relative of Khusrau, ${ }^{81}$ and there are various hints within the sources that she arrived in the Roman empire not of her own initiative, but rather in his entourage. ${ }^{82}$ We might imagine, then, that the presence of a high-profile (Nestorian) Christian formed part of that aforementioned attempt to shroud Khusrau's appeal to Constantinople with the expectation of conversion. ${ }^{83}$ Stephen's Life, however, obfuscated this fact, and recast the saint's tale for the purposes of Roman propaganda.

Soon after, that tale would be appropriated once again. At some point in the months following the death of Domitian on 12.i.602, a prominent author of the Constantinopolitan patriarchate, the priest Eustratius, completed a new rendering, into Greek, of Stephen's Life. ${ }^{84}$ Eustratius's version maintains the basic narrative and themes of its model, but amplifies the role of Domitian (who had perhaps been its patron), ${ }^{85}$ and adds an anecdote in which the saint, foreseeing her imminent death, refuses an invitation of 'the emperors' (sc. Maurice and Theodosius) to Constantinople, and instead entreats God for the preservation of the emperors' 'faithful state' and capital, the multiplication of victories over barbarians, and the conversion of the impious. ${ }^{86}$ Then Golinduch surrenders her soul, and her death is

\footnotetext{
${ }^{79}$ Georgian Life of Golinduch trans. (Lat.) G. Garitte, 'La Passion géorgienne de Sainte Golindouch,' Analecta Bollandiana 74 (1956) 405-40, at 426-440. The prophecy occurs at ch. 17.

${ }^{80}$ See Theophylact, History 5.12; Evagrius Scholasticus, Ecclesiastical History 6.20; John of Nikiu, Chronicle 96; Nicephorus Callistus, Ecclesiastical History 18.25 (PG 147 377). On the relation of these sources to Stephen's Life (and to John of Epiphania) see Olajos, Sources de Théophylacte 67-82.

81 This is stated in Georgian Life of Golinduch 2 (Garitte 426): genere Persa, quae propria erat Chosrois regis Persarum; cf. Theophylact, History 6.12.1.

${ }^{82}$ Thus Nicephorus Callistus, Ecclesiastical History 18.25 (PG 147 377) places her at Circesium (and Dara) upon her flight; Eustratius Presbyter, Life of Golinduch 18 ed. A. Papadopoulos-Kerameus, Analecta Hierosolumitikēs stachuologias (5 vols, Petropoli, 1891-98) vol. 4 149-74 [with the additional, somewhat strange, colophon from Athon. Dionysii 145 at ibid. vol. 5 395-6] places her at Nisibis on the eve of her flight (distinct from the Nitzion/Nision at ibid. 16, and Georgian Passion 2, 12-14, 20?), and Theophylact, 5.12.8-10 places her baptism and persecution there. Within Roman territories, sources then place her at Hierapolis, foreseeing Khusrau's arrival (Georgian Life of Golinduch 16-17; Eustratius, Life of Golinduch 21; Theophylact, History 5.12). For Khusrau's route cf. above n. 0000, and for her suggested arrival in Khusrau's entourage see also P. Peeters, 'Sainte Golindouch, martyre perse († 13 juillet 591),' Analecta Bollandiana 62 (1944) 74-125, at 117-118. Golinduch is also presented as a devotee of St Sergius, in whose shrine she was buried (Georgian Life of Golinduch 15; Eustratius, Life of Golinduch 20, 24, 26).

${ }^{83}$ Golinduch's Nestorianism, natural but obfuscated in other sources, is made explicit in John of Nikiu, Chronicle 96.

${ }^{84}$ The death of 'most blessed' Domitian is implied at Eustratius, Life of Golinduch 22, and dated to 12.i.602 in Theophanes, Chronographia AM 6094.

${ }^{85}$ Eustratius, Life of Golinduch 22; cf. Georgian Life of Golinduch 16-17.

${ }^{86}$ Eustratius, Life of Golinduch 23-24.
} 
dated to $13^{\text {th }}$ July of the $9^{\text {th }}$ indiction (592), 'while Chosores the Younger was king of the Persians' empire, but of our state of Christians Maurice and Augusta and Theodosius and his remaining children' ${ }^{87}$

The author had good reason to be confident in Golinduch's reported intercession. For alongside the peace with Persia, Maurice's son and co-emperor Theodosius had in November 601 married the daughter of Germanus. ${ }^{88}$ In the last days of Tiberius, this Germanus-who was the grandson of the famous Germanus, cousin of the emperor Justinian ${ }^{89}$-had been made co-Caesar alongside Maurice and, like the latter, was betrothed to one of his daughters. ${ }^{90}$ Although Maurice succeeded as sole Augustus upon Tiberius's death, ${ }^{91}$ throughout Maurice's reign Germanus no doubt presented a potential focal point for discontents. ${ }^{92}$ The marriage of his daughter to Theodosius thus united two grand imperial families, promised the perpetuation of the new dynasty, and curtailed the potential for dissent. ${ }^{93}$

Nevertheless Eustratius's Life, in retrospect, might appear somewhat tragic. For within a few months of its composition, it was rendered more or less obsolete. On 27.xi.602, Maurice was murdered in a violent coup. ${ }^{94}$ The emperor's dramatic death is described in a number of texts and traditions, but the fullest and most important account is contained in the History of Theophylact Simocatta. This

\footnotetext{
${ }^{87}$ Eustratius, Life of Golinduch 26 (Papadopoulos-Kerameus vol. 4 173-174).

88 Theophanes, Chronographia AM 6094, a date which is supported in Theophylact, History 8.4.10-11. Paschal Chronicle (Dindorf 693) claims that the marriage took place over the week 9-15.ii.602. Whitby and Whitby, Theophylact 215 n. 17 (and Paschal Chronicle 142 n. 399) suggest that the week-long festivities in February might have celebrated the earlier marriage, and been intended to restore 'popular goodwill' following a reported riot on 2.ii.602; for which see below n. 0000.

${ }^{89}$ See now Feissel, 'Trois notes' 258-262 who-on the basis of Theodore Skutariotes, Synopsis Chronikē ed. K. N. Sathas, Mesaiōnikē Bibliothēkē (7 vols, Venice, 1872-1894) vol. 7 104-makes a decisive identification of the Caesar Germanus with the son of the patrician Justinian (PLRE III Iustinianus 3) to whom Tiberius promises a daughter in Gregory of Tours, History 6.30 (as suggested in some previous literature; see also PLRE III Germanus 5). He was thus also the grandson of Justinian's cousin Germanus (PLRE II Germanus 4), and not his son (PLRE III Germanus 3); pace Whitby, Emperor Maurice 7; Pfeilschifter, Der Kaiser 277-278.

${ }^{90}$ I thus assume that the Caesar Germanus (PLRE Germanus 5) is identical with the Germanus who becomes Theodosius's son-in-law (PLRE Germanus 11). The marriages occurred on the 5.viii.602; see Theophanes, Chronographia AM 6074; Theodore Skutariotes, Synopsis Chronike (Sathas, vol. 7 104). See also the famous medallion, perhaps for the wedding of Germanus and Tiberius's daughter Charito (the bride wears a diadem, and an inscription reads XAIPE KEXAPITSMENH), reproduced in e.g. M. Vassilaki, Mother of God: Representations of the Virgin in Byzantine Art (Milan, 2000) 290.

${ }^{91}$ Maurice was made Augustus on 13.viii.602, eight days since becoming Caesar, and one day before Tiberius's death; see Pashcal Chronicle (Dindorf 690); Theophanes, Chronographia AM 6074; with John of Ephesus, Ecclesiastical History 3.5.13; Evagrius Scholasticus, 5.22; Gregory of Tours, History 6.30. None of these sources acknowledges a contested succession (cf. also the previous above), and John of Nikiu, Chronicle 94 (Zotenberg 168) claims that Germanus (warmadyānos, but here called Tiberius’s son-in-law) was Tiberius's preferred successor, but refused the crown (as perhaps he did also later; see Theophylact, History 8.10.4). As Feissel, 'Trois notes' 264 suggests, if this refusal happened soon after Germanus’s elevation as co-Caesar, it would explain his striking absence from the two formulae of a novel promulgated on 11.viii.602 ed. C. E. Zachariä von Lingenthal, Jus Graeco-Romanum Pars III: Novellae constitutiones imperatorum post Justinianum (Leipzig, 1857) 30-31 (with the corrected regnal formula in Feissel, 'Trois notes' 270 n. 103), which also calls Maurice Caesar.

92 See the reported offer of the emperorship to him during the rebellion of Phocas, and Maurice's subsequent suspicion of his ambitions (Theophylact, History 8.8-9).

${ }^{93}$ See also Feissel, ‘Trois notes' 266-267, who also considers the naming of two of Maurice’s children after Justin and Justinian (see above n. 0000) to signal the same rapprochement.

${ }^{94}$ For the date: Paschal Chronicle (Dindorf 694). For its possible commemoration in the Synaxarium: V. Grumel, 'La Mémoire de Tibère II et de Maurice dans le Synaxaire de Constantinople,' Analecta Bollandiana 84 (1966) 249-253; and cf. G. Garitte, Le calendrier palestino-géorgien du Sinaiticus 34 (Xe siècle) (Brussels, 1958) 87. For a possible Heralican memorial at the site: C. Mango, 'A Memorial to the Emperor Maurice?' Deltion 24 (2003) 15-20, esp. 15-17.
} 
account reports that after an imperial command to winter north of the Danube, the soldiers of the Balkans mutinied against Maurice and marched on Constantinople. A letter was then sent from the mutineers under Phocas to Maurice's son Theodosius asking him, or his new father-in-law Germanus, to assume the throne. ${ }^{95}$ The emperor, suspecting treason, attempted to arrest Germanus, but then faced a popular revolt and was forced to flee the capital in the guise of a commoner, reaching the Church of St Autonomus (at Praenetus on the Gulf of Nicomedia) ${ }^{96}$ along with his wife, children, and the praetorian prefect Constantine Lardys. ${ }^{97}$ In the meantime, the Green faction invited Phocas to the Hebdomon, where he was acclaimed emperor and coronated in the Church of John the Baptist. At the Hippodrome on the following day, however, a breach of ceremonial protocol led the Blues to offer a portentous threat: 'Maurice is not dead'. Thus Phocas sent soldiers after the emperor, who intercepted and brought him to the harbour of Eutropius (at Chalcedon), where he and his sons were put to the sword. ${ }^{98}$

Two curious features of the wider narrative concern the fate of Maurice's sons. Theophylact reports that the imperial nurse had substituted her own infant for one of the princes, but that Maurice himself revealed the subterfuge to his murderers. ${ }^{99}$ He also claims that while at St Autonomus Maurice-after showing to Theodosius his ring, and commanding him not to return unless he should again be shown it-dispatched him as ambassador to Khusrau, to beg him to reciprocate his earlier support. Theodosius then fled, and along with the praetorian prefect Constantine, reached Nicaea. Soon after however, when the Blues had offered their ominous reminder in the Hippodrome, but before Phocas has dispatched the soldiers after Maurice, the emperor is said, in Theophylact's telling, to have sent the aforementioned ring to Theodosius at Nicaea, whence he returned to the capital. ${ }^{100}$ Theophylact's subsequent narrative suggests that Theodosius was murdered with his father, for we read that the corpses of the 'emperors' could soon be seen rolling in the tide on the coastline at Chalcedon. ${ }^{101}$ However, after several further sections - a reported speech of Theophylact, delivered from the pulpit and concerned with the massacre; the exhibition of the victims' heads at the Hebdomon; the punishment visited on Phocas' soldiers; and the murder of several more prominent individuals (Maurice's brother Peter; the generals Comentiolus and Philippicus; the latter's subordinate George; the domesticus Praesentinus)—we find a specific indication of Theodosius fate. ${ }^{102}$ For we are then informed that he had, in fact, fled upon reaching the Church of St Autonomus at Praenetus, and that Phocas, apprised of this, had sent an agent, Alexander, who pursued and then murdered him and Constantine at a place called 'Diadromoi', ${ }^{103}$ said elsewhere to be near Acritas (also, like Praenetus, on the Gulf of Nicomedia). ${ }^{104}$

\footnotetext{
${ }^{95}$ Note that in Chronicle to 1234 83, Michael the Great, Chronicle 10.24, and Agapius, Universal History (Vasiliev vol. 3 448) it is Peter, Maurice's brother, whom the rebels ask to assume the throne; cf. PLRE III Petrus 55.

${ }^{96}$ See R. Janin, Les églises et les monastères des grands centres byzantins (Paris, 1975) 86-87.

${ }^{97}$ Constantine: PLRE III Constantinus qui et Lardys 33.

${ }^{98}$ Theophylact, History 8.6.2-11.6 (who neglects to make clear that the emperor and his family were intercepted at Praenetus, as in Paschal Chronicle [Dindorf 694]); Theophanes, Chronographia 6094.

${ }^{99}$ Theophylact, History 8.11.5 (de Boor and Wirth 305); cf. Theophanes, Chronographia 6094.

100 Theophylact, History 8.9.11, 8.11.1; cf. Theophanes, Chronographia AM 6094 (de Boor 288-289), who here reports the dispatch of Theodosius but not his return.

101 Theophylact, History 8.12.2. According to Patria 3.185 ed. T. Preger, Scriptores originum Constantinopolitanarum (2 vols, Leipzig, 1901-1907) vol. 2 274, Maurice’s sister (PLRE III Gordia 2) retrieved the bodies and placed them in the Monastery of St Mamas.

102 Theophylact, History 8.12.3-13.2.

${ }^{103}$ Theophylact, History 8.13.3.

${ }^{104}$ Paschal Chronicle (Dindorf 694).
} 
The account of Theophylact insists, then, that all of Maurice's sons were victims of the massacres. But he nevertheless admits a rumour that Alexander, at the instigation of Germanus, had spared Theodosius and slain a lookalike in his place; and that the real Theodosius had then travelled around the east, before coming to Colchis (i.e. Lazica), ending his life in 'the deserts of the barbarians' ${ }^{105}$ Then he states,

'And so this story re-echoed throughout the whole inhabited world, but it was some barbarian error that gave it birth. For, after laboriously investigating this matter as far as possible, we discovered that Theodosius also shared in the slaughter. For those who profess that the boy did not die are blustering with meagre evidence; for their story is that, alone of those slain, the head of the emperor Theodosius was not displayed. ${ }^{106}$

Theophylact, now nearing the conclusion to his narrative, then turns to an assorted collection of anecdotes about Maurice, and to a short account of the failed attempts of Phocas to court Khusrau, and of the subsequent declaration of war. ${ }^{107}$ But, then, however, he makes a sudden return to the fate of Theodosius:

'In these days, error came upon the inhabited world, and the Romans supposed that Theodosius was not dead. And this became an opportunity for very great evils, and this false supposition contrived an abundance of slaughters. When the rumour spread to the palace, the tyrant [Phocas] was greatly distressed and destroyed Alexander with the sword. For it was necessary for Phocas to destroy his co-partners in the tyranny, and to escort to extraordinary deaths his fellow allies in the evil. For collaboration in evil is incapable of establishing the firm friendship of like minds. ${ }^{108}$

This, in fact, is the final paragraph of the entire text - an indication that the issue was, for the author, of crucial importance. ${ }^{109}$ Thus where, as we have seen, Evagrius Scholasticus had earlier finished his own oeuvre with the hope which Theodosius's birth offered to the emperor and state, Theophylact finished his with an absolute insistence on his death.

The basic sequencing of this narrative was later adopted in the Chronographia of Theophanes, who supplements Theophylact's account with material from other sources. ${ }^{110}$ For Theophanes, the issue of Theodosius's survival seems less urgent, but upon acknowledging the rumour he nevertheless parts company with his source, and expands upon the perceived context:

\footnotetext{
105 Theophylact, History 8.13.4 (de Boor and Wirth 309).

${ }^{106}$ Theophylact, History 8.13.5-7 (de Boor and Wirth 309) trans. Whitby and Whitby, Theophylact 231.

107 Theophylact, History 8.13.7-15.7.

${ }^{108}$ Theophylact, History 8.15.8-9 (de Boor and Wirth 314) trans. Whitby and Whitby, Theophylact 235.

${ }^{109}$ There is no need to think this ending discordant or disordered, as some scholars have; see the discussion in Whitby, Emperor Maurice 47-48, and cf. below for the concluding chapters of the texts.

${ }^{110}$ On Theophanes' use of Theophylact see M. Whitby, 'Theophanes' Chronicle Source for the Reigns of Justin II, Tiberius and Maurice (A.D. 565-602),' Byzantion 53 (1983) 312-345, at 314-316, 324-337 (although cf. also n. 0000 below); cf. Olajos, Sources de Théophylacte 113-126.
} 
'As for Maurice's son Theodosios, a rumour prevails that he escaped and was saved. This rumour was fanned by Chosroes, emperor of the Persians, who on different occasions uttered different lies, alleging that he had Theodosios with him and was making provision that he should take possession of the Empire of the Romans; whereas he was himself hoping to gain control of the Roman Empire by deceit; whereof he was convicted in many ways, especially by starting sudden wars and inflicting great damage on the Roman lands. ${ }^{111}$

In Theophanes' telling, then, the rumour is a piece of Persian propaganda, of deliberate disinformation designed to fan the flames of dissent within the Roman empire. For both Theophylact and Theophanes, therefore, there could be no question that Theodosius - the Augustus born in the purple, and adopted son of the empire—-had been slain. ${ }^{112}$

\section{Theodosius Redivivus}

The insistence of Theophylact and Theophanes at once raises the reader's suspicion. Indeed, the narrative of Theophylact (and, to a lesser extent, of Theophanes) is replete with patent problems in respect of Theodosius: for example, Maurice's shifting motives, dispatching then recalling him; Theodosius's own wavering resolve, fleeing, returning, then fleeing again; his strange failure twice to escape the reach of agents or of messengers from Constantinople; and his rapid oscillation between distant centres. It is obvious, in fact, that the same accounts attempt to tread something of an interpretative tightrope, caught between two imperatives: first, to recognise the rumours about Theodosius (and the nurse's son), and acknowledge his flight from the capital; but second, to posit his return, and insist upon his death alongside, or soon after, his father. The insistence on Theodosius's death is indeed characteristic of texts produced in Greek, but our suspicions of their narrative are confirmed when our gaze turns instead to other languages. Later Frankish, Coptic, West Syrian and Melkite sources, let us note, follow the same Greek account in suggesting that all of Maurice's sons were slain. ${ }^{113}$ But in the East Syrian, Armenian, and Islamic traditions, we encounter several accounts which affirm Theodosius's flight and survival.

111 Theophanes, Chronographia AM 6095 (de Boor 291) trans. C. Mango and R. Scott, The Chronicle of Theophanes Confessor: Byzantine and Near Eastern History, A.D. 284-813 (Oxford, 1997) 419.

112 Note also the unique report in Cedrenus, Compendium of Histories ed. I. Bekker, Georgius Cedrenus Ioannis Scylitzae ope (2 vols, Bonn, 1838-39) vol. 1: 'But after Theodosius the son of Maurice had been sent to Khusrau, as rumour has it, Phocas sent after him and seized him at Nicaea, and when he had come to Leukaktē ordered for him to be killed. But he asked to receive the holy mysteries before being so killed. When he had received them, he gave thanks to God and took a stone from the ground, and struck it three times against his chest. He then prayed: "Lord Jesus Christ, you know that I have wronged no man upon the earth. Now as your power commands, so let it be for me." He said this and was beheaded. But some say that this Theodosius-after he had been sent

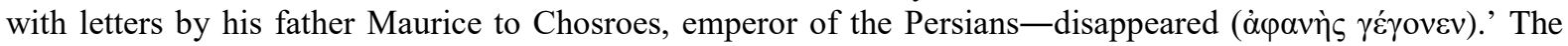
source of this vignette is at present unclear.

${ }^{113}$ Frankish: Paul the Deacon, History 4.26 (Capo 202) (listing Theodosius, Tiberius, and a 'Constantine' as Maurice's murdered sons). Coptic: John of Nikiu, Chronicle 103. West Syrian: Chronicle to 724 (Brooks 145); Jacob of Edessa, Chronicle ed. E.W. Brooks in Chronica minora III, CSCO 5, SS 5 (Paris, 1961) 261- 330, at 324; Chronicle of Zuqnin ed. J.-B. Chabot, Chronicon anonymum pseudo-Dionysianum vulgo dictum, CSCO 91, 104, SS 43, 53 (2 vols, Paris, 1927-65) vol. 2148 (which also presents Maurice and Theodosius as co-emperors for twelve years); Chronicle to 1234 83; Michael the Great, Chronicle 10.24, 10.25. Melkite: Agapius, Universal 
Two East Syrian texts places Theodosius at the court of Khusrau in late 602 or 603, and then again at the siege of Dara, which we know to have extended for eighteen months across 603 and $604 .{ }^{114}$ Thus the Khuzistan Chronicle (c.652) reports that Theodosius, alone of Maurice's sons, escaped Phocas' massacre, and that Khusrau received him with honour, and had the catholicos crown him in church. Khusrau then supplied soldiers to Theodosius, who fought a force of Phocas near Dara, and was crushed. ${ }^{115}$ At this point, Theodosius appealed for more troops, and Khusrau, alongside the catholicos (Sabrisho), marched out, defeated the Romans, and seized Dara. ${ }^{116}$ Nothing more is said of him, and the implication seems to be that he died at Dara. This is made explicit in a later version of the same tradition contained within the Chronicle of Seert - a tenth-century compilation which nevertheless integrates far earlier texts composed in and around the Nestorian catholicosate. ${ }^{117}$ The text notes how the peaceful relations between the Persian and Roman empires were shattered with the murder of Maurice, and how Khusrau then visited the aged catholicos Sabrisho (that former favourite of the Roman emperor) to seek divine approval for his imminent campaign 'to avenge the blood of the pious Maurice and to seat in his place Theodosius, who escaped the massacre.' ${ }^{118}$ In a subsequent chapter dedicated to the 'Tale of Theodosius the son of Maurice, king of the Romans', the Chronicle claims that Theodosius fled to Khusrau who, vowing vengeance on the murderers of Maurice, coronated and promised to restore him. Then he dispatched Theodosius, with some soldiers and a 'cruel, inhuman, and hard general' to besiege Dara. Soon after Khusrau, along with the catholicos Sabrisho, reinforced the siege, and when the fortress fell, Khusrau abandoned his armies and returned to his capital. The account, then, is similar to that contained within the Khuzistan Chronicle but here reaches a blunt, unelaborated, conclusion: 'Then Theodosius died, having been poisoned." 119

Another tradition around Theodosius survives in the Armenian History attributed to Sebēos (c.661). After a brief account of the coup of Phocas and the murder of Maurice and his sons, Ps.-Sebēos reports:

\begin{abstract}
'The emperor Maurice had a son named T'ēodos. A rumour spread over the whole country that $\mathrm{T}^{\prime}$ 'èodos had escaped and gone to the Persian king. Then there was no little turmoil in the Roman empire - there in the royal capital, and in the city of Alexandria in Egypt, and in Jerusalem and Antioch. In all regions of the land they took up the sword and slaughtered each other.' ${ }^{120}$
\end{abstract}

History (Vasiliev vol. 3 448); Eutychius of Alexandria, Annals (Alexandrian Recension) 27 (Breydy 118) (excepting the son whom the nurse substitutes, as below n. 0000).

114 Ps.-Sebēos, History 31 (Abgaryan 107), with n. 0000 below for the eighteen months. On the siege of Dara, see Chronicle to 724 (Brooks 145), its fall dated to AG 915, ind. 9 (603/4); Michael the Great, Chronicle 10.25, dated to AG 915, Phocas 2 (603/4); Khuzistan Chronicle (Brooks 19) gives Khusrau 14 (603/4). Theophanes, Chronographia AM 6118 also implies 604. Chronicle to 123486 and Chronicle of Seert 79 both claim that the siege lasted nine months, and the latter's synchronism for the death of Sabrisho soon after the siege (ibid. 70) demands 18.ix.603; but see Flusin, Saint Anastase vol. 2 71-74.

115 This alleged battle is otherwise unknown. The Roman forces known to have been sent in 603-604 focused their attentions on Narses at Edessa; see Theophanes, Chronographia AM 6095-6096, with PLRE III Germanus 13, Leontius 29.

${ }^{116}$ Khuzistan Chronicle (Guidi 20-21).

117 See P. Wood, The Chronicle of Seert: Christian Historical Imagination in Late Antique Iraq (Oxford, 2013), esp. 176-220.

${ }^{118}$ Chronicle of Seert 70 (Scher vol. 4 500).

${ }^{119}$ Chronicle of Seert 79 (Scher vol. 4 519-520).

${ }^{120}$ Ps.-Sebēos, History 31 (Abgaryan 106) trans. R. W. Thomson in id. and J. Howard-Johnston, The Armenian History Attributed to Sebeos (2 vols, Liverpool, 1999) vol. 157. 
In the final part of this quotation, and in the subsequent section, Ps.-Sebēos telescopes the aftermath of Phocas' coup with the Heraclian seizure of Egypt (609-610), and the factional violence which accompanied it. ${ }^{121}$ But he also there refers to the anti-Phocan rebellion of the Roman general Narses in Mesopotamia, and his seizure of Edessa. ${ }^{122}$ It is probable that this occurred in 603. ${ }^{123}$

Ps.-Sebēos continues to report Khusrau's siege of Dara. While that siege was ongoing, he claims, Khusrau marched upon Edessa, where the Roman general Narses dressed 'a youth in royal garb', and dispatched him to the Persians with the words: 'This is the son of king Maurice, T'ēodos; do you have pity on him, just as his father had on you. ${ }^{, 24}$ Khusrau then returned to the siege of Dara and, with the pseudo-Theodosius in his entourage, captured it after a year and a half. After this, a later chapter claims, the shah sent 'the caesar $\mathrm{T}$ 'èodos, the so-called son of Maurice' with a Persian general to Armenia where, following a significant Roman defeat, the inhabitants of the fortress of Karin (Theodosiopolis) capitulated:

'Then the caesar T'ēodos came forward, saying: 'I am your king.' They then acquiesced and opened [the gate]. The chief men of the city came out and presented themselves to him. On returning they persuaded the city that he really was $T^{\prime}$ ēodos, son of Maurice. Then, having opened the gate, they submitted., ${ }^{125}$

Ps.-Sebēos places this Armenian campaign in Khusrau's eighteenth year (607/8), a date which is supported in other sources. ${ }^{126}$ This, then, is the latest witness to Theodosius's possible survival.

Although the representation of Theodosius differs in all three of our texts, it is possible that all three reflect contemporaneous Sasanian propaganda, if not the cluster of traditions contained in the Sasanian historiographical tradition. ${ }^{127}$ Later Islamic texts which depend on that tradition do accord Theodosius a prominent role, although he is here not identified with a son of Maurice said to have survived the massacre. ${ }^{128}$ His place in later Islamic (and New Persian) texts is deserving of a more

\footnotetext{
${ }^{121}$ On this violence see P. Booth, 'Shades of Blues and Greens in the Chronicle of John of Nikiu,' Byzantinische Zeitschrift 104 (2011) 555-601. Cf. below n. 0000.

122 Ps.-Sebēos, History 31 (Abgaryan 106).

${ }^{123}$ On the revolt of Narses see Theophanes, Chronographia AM 6095; Michael the Great, Chronicle 10.23 (undated); Chronicle to 1234 85, placing Narses at Antioch upon his rebellion, before his flight to Edessa; Jacob of Edessa, Chronicle (Brooks 324) (placed after Phocas' coup); Chronicle of Zuqnin (Chabot vol. 2 148) (placed in AG 914 = 602/3); Chronicle to 819 ed. A. Barsaum in Chabot, Chronicon anonymum ad ... 1234 vol. 1 3-22, at 10 (dated AG $912=600 / 1$ ). Theophylact, History 8.15.4 suggests that Maurice had removed Narses from Dara at the end of his reign, and replaced him with a Germanus (cf. PLRE III Germanus 13), at the Persians' request.

${ }^{124}$ Ps.-Sebēos, History 31 (Abgaryan 107) trans. Thomson, Armenian History 58.

125 Ps.-Sebēos, History 33 (Abgaryan 110-111) trans. Thomson, Armenian History 63.

${ }^{126}$ Narratio de Rebus Armeniae 112 (dating the siege of Theodosiopolis to Phocas 5 [606/7] but also Khusrau 20 [609/10]). See also Flusin, Saint Anastase vol. 2 80-81.

${ }^{127}$ On the place of this tradition within Ps.-Sebēos and the Chronicle of Seert see J. Howard-Johnston, Witnesses to a World Crisis: Historians and Histories of the Middle East in the Seventh Century (Oxford, 2010) 82-83, 325; T. Greenwood, 'Sasanian Echoes and Apocalyptic Expectations: A Re-evaluation of the Armenian History Attributed to Sebeos,' Le Muséon 115 (2002) 323-397, at 327-347; Wood, Chronicle of Seert 172-174.

${ }^{128}$ For the dependence on Sasanian tradition see e.g. M. R. Jackson Bonner, Al-Dinawari's "Kitab al-Akhbar alTiwal": An Historiographical Study of Sasanian Iran (Leuven, 2015); J. Howard-Johnston, 'Al-Tabari on the Last Great War of Antiquity,' in id. East Rome, Sasanian Persia VI, esp. 8-12. For wider discussion: P. Wood, 'The
} 
thorough investigation, but we will restrict ourselves to some of the more fulsome and accessible: the General History of Dīnawarī; the Annals of Tabarī; and the anonymous Nihāyat al-'Irab fì ahbar alFurs wa-l-'Arab. Here it is Theodosius role during the reign of Maurice, rather than after it, which is so striking. For these texts make the arresting claim that Maurice-having acquiesced to Khusrau's request for support in 591— sent to him 'his son Tiyādūs', at the head of a large force. ${ }^{129}$ In the account of Dīnawarī, Theodosius then assumes a significant role in the campaign, overseeing the battle against Bahram from a golden throne (shared with Khusrau and set upon a hill), commenting on the action, and dissuading Khusrau from an aborted bout of single combat; ${ }^{130}$ while in the Nihayat al-'Irab Theodosius accompanies Khusrau to a banquet at which the latter agrees to sport, to the shock of his supporters, a gift from the emperor - a robe embroidered with crosses. ${ }^{131}$ Although the dispatch of Theodosius, then a child of eight, on campaign is not at all credible, the role accorded to him nevertheless serves to presage the flight of a Roman prince later in the texts, where it is said that one of Maurice's son escaped from Phocas and sought refuge with Khusrau, who put him at the head of a large force, alongside three Persian generals. ${ }^{132}$ Dīnawari differentiates this surviving son from Theodosius, who is said to have died alongside his father, but does not refer to the other son's fate. ${ }^{133}$ Likewise Tabarī does not assert that the sole surviving son is Theodosius, but offers more detail on that son's campaigns within the Roman empire. Thus when, at Khusrau's command, the Persian generals then conquered and devasted the Roman East - as an act of vengeance for the Romans' violence against Maurice-it is nevertheless noted that, '[N]one of the Romans acknowledged Mawrīq's son as their ruler, or offered him any obedience. ${ }^{134}$ Within the Sasanian historiographical tradition as reflected in Islamic texts, then, Theodosius has an elevated role in the restoration of Khusrau; and here we also discover, if not Theodosius, then a son of Maurice, and claimant to the Roman throne, in the entourage of the invading Persian armies.

We have seen above that both Theophylact and Theophanes acknowledge rumours of Theodosius's survival, and that Theophanes dismisses these as a form of information warfare generated at the Sasanian court. Should we suppose, then, that the survival of Theodosius is a piece of deliberate disinformation, generated in the context of war, enshrined within Sasanian annals, and echoed in East Syrian and Armenian texts? And even if the person who claimed to be the eldest son of Maurice, and

Christian Reception of the Xwadāy Nāmag: Hormizd IV, Khusrau II, and their Successors,' Journal of the Royal Asiatic Society Ser. 3, 26 (2016) 407-422.

${ }^{129}$ See Dīnawarī, General History (Girgas 96); Țabarī, Annals (de Goeje vol. 2 999), calling Tiyādūs the brother of Mawrīq (Maurice), and stating that the general who led the campaign was one Sarğīs (Sergius) (who also appears in Ferdowsi's Shahnameh, as below); Nihāyat al-'Irab, as set out in E. G. Browne, 'Some Account of the Arabic Work entitled "Niháyatu'l-irab fi akhbári'l-Furs wa'l-'Arab,” particularly of that part which treats of the Persian Kings,' Journal of the Royal Asiatique Society 32 (1900) 195-259, at 239, which reports the dispatch of both Theodosius, called a son, and Maria (cf. above n. 0000). Theodosius also appears as the chaperone of Maria in other Islamic and Persian texts dependent on the Book of Lords: see al-Mas'ūdī, Fields of Gold (Barbier de Meynard and Pavet de Courteille vol. 2 221); Ferdowsi, Shahnameh (Mohl vol. 7 110-111), calling him 'Neïathous' and the brother of Maurice.

${ }^{130}$ Dīnawarī, General History (Girgas 96-97, also 102). Cf. Ferdowsi, Shahnameh (Mohl vol. 7 132-135).

${ }^{131}$ Nihayat al- 'Arab, cited in Browne, 'Some Account' 240. Cf. Ferdowsi, Shahnameh (Mohl vol. 7 146-150).

132 Dīnawarī, General History (Girgas 110); Tabarī, Annals (de Goeje vol. 2 1001-1002). Note that in the latter the son is also coronated in Persia.

${ }^{133}$ Dīnawarī, General History (Girgas 110). But note the perhaps conflicting claim, put into the mouth of Khusrau at ibid. 114, that he accompanied Theodosius when he returned to his kingdom. This does not seem to mean Theodosius's return after the suppression of Bahram; cf. ibid. 102 for the simple dismissal of Theodosius from Khusrau's court.

${ }^{134}$ Țabarī, Annals (de Goeje vol. 2 1002) trans. C. E. Bosworth, The History of al-Tabari Volume V: The Sasanids, the Byzantines, the Lakhmids, and Yemen (New York, NY, 1999) 319. 
who is said to have been present at two important sieges, is a real historical actor, might he have indeed been an impostor, a creation of Khusrau and/or of Narses?

There is good reason to suppose that Theodosius did indeed escape the massacre. Even without wider witnesses, and despite his vociferous objections, the obvious implication of Theophylact's entries on Theodosius - which culminate in Phocas's execution of Alexander-is that the emperor considered the rumours of Theodosius's escape to be true. Alexander was an officer in the Balkans and agent of Phocas who, before his commission to murder Theodosius, had been a messenger to Maurice and, later, to the circus factions. ${ }^{135}$ His execution under Phocas is also recorded in the Chronicle of John of Nikiu (c.690) which, in these sections, depends upon an otherwise unique source or sources recording events in Constantinople and Alexandria. Having reported Phocas' coup, and the death of the emperor with his 'five sons', the Chronicle states:

'There were certain people who accused Alexander ('ala 'askandaros), who was one of the lords ('ag $\bar{a}$ ' $z z t)$. He was a wise man, and beloved by all the people of Constantinople. People said to Phocas, 'This man Alexander wants to kill you and become emperor in your stead.' For this Alexander had married ('awsaba) a daughter of Maurice. Thereupon Phocas imprisoned Alexander and Kudis [Goudouïs?] ${ }^{136}$ and other eunuchs (had dawān), and sent them to the city of Alexandria so that they might be imprisoned there. A short time after, Phocas sent [an order] to Justin (yustinass), ${ }^{137}$ the city of Alexandria's general (mak $\left.{ }^{w} a n n ə n\right)$, that he execute Alexander and those with him.' ${ }^{138}$

It should be remembered that the Chronicle is not accessible except in an Ethiopic translation of a lost Arabic paraphrase of a Coptic original, so that the potential for distortion in transmission is significant. Here, it has been suggested that the Chronicle somehow confuses Alexander with Germanus, who was indeed executed later in the reign of Phocas. ${ }^{139}$ But the name 'Alexander' is precise, and the biographical details do not match those of Germanus, who had not 'married a daughter of Maurice', and who is said to have been executed on Prote, not at Alexandria. ${ }^{140}$ Nevertheless we must suspect some confusion. Maurice's three daughters (Anastasia, Theoctiste, Cleopatra) were placed under house arrest, and then confined to a convent, soon after their father's death, and it seems improbable that Phocas would have allowed such a match - even if one of those daughters had proved willing to wed the reported executioner of her eldest brother. ${ }^{141}$ The Ethiopic 'had married a daughter of Maurice' thus seems to represent a significant distortion, even if the original is irrecoverable. But what seems

\footnotetext{
135 See Ps.-John of Antioch, Chronicle 318 (= De ins. 108); Theophylact, History 6.8.9, 7.2.6, 8.10.11-13.

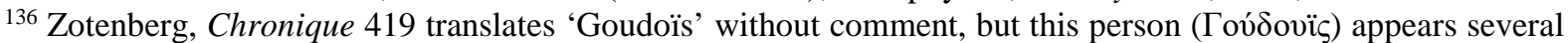
times in the Balkans narrative of Theophylact, where he is called a taxiarchos (History 7.12.7), a middle-ranking position in the field armies; see PLRE III Guduin 1. ${ }^{137}$ Otherwise unknown.

137 Otherwise unknown.

138 John of Nikiu, Chronicle 104 (Zotenberg 184).

139 See Zotenberg, Chronique 419 n. 1.

${ }^{140}$ Marriage of Germanus: above n. 0000. Execution on Prote: Theophanes, Chronographia AM 6098.

${ }^{141}$ Fate of the daughters: see the accounts in Theophylact, History 8.15.1, Paschal Chronicle (Dindorf 695, Theophanes, Chronographia 6095, 6098; John of Nikiu, Chronicle 103; Patria 3.185; Synopsis Chronikē (Sathas vol. 7 104-105); cf. also Synaxarium of the Constantinopolitan Church ed. H. Delehaye, Synaxarium ecclesiae Constantinopolitanae (Brussels, 1902) 207-208 for an otherwise unknown daughter 'Sopatra'. The daughters are named in Paschal Chronicle (Dindorf 693, 697).
} 
significant is that Phocas' arrest of Alexander is again put in the context of Maurice's surviving children, and their perceived threat to Phocas's regime.

Despite his denials, Theophanes, too, provides significant evidence for Theodosius's survival. Across two separate entries (for 606/7 and 608/9) and with some duplication, Theophanes describes a plot against Phocas which revolved around Constantina, the wife of Maurice, and Germanus, the fatherin-law of Theodosius. The plot, however, was revealed, and culminated in the execution of Constantina and her three daughters; Germanus and his daughter (the wife of Theodosius); and a raft of coconspirators. ${ }^{142}$ But a striking sentence perhaps reveals the hidden purpose, or hope, of their plot: 'As the rumour spread about that Theodosius, the son of Maurice, was alive, both Constantina and Germanus had high hopes on that account.' ${ }^{143}$ The suggestion, therefore, is that long after Phocas' usurpation, Theodosius's own mother and father-in-law still expected him to reclaim his throne.

The emperor Phocas, therefore, was not alone in his apparent suspicion that Theodosius had escaped. That suspicion is in fact confirmed in a neglected piece of evidence from the reign of Phocas itself. The Greek Anacreontics of Sophronius of Jerusalem includes a poem which we can situate, with some confidence, during the author's time in Alexandria (c.603-c.619). ${ }^{144}$ In one manuscript, the title of the poem bears the striking title, 'On the father Menas, steward of the Ennaton at Alexandria, who

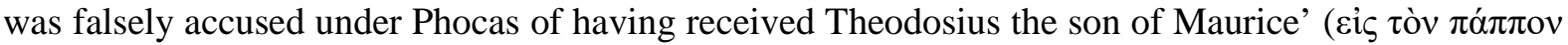

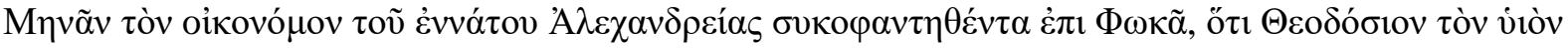
Mavpıkíov $\dot{\varepsilon} \delta \varepsilon \dot{\varepsilon} \xi \alpha \tau$ ). ${ }^{145}$ It describes how a 'son' of Menas (sc. a monk of the Ennaton), 'a new Judas', conspired with a prostitute and claimed that 'the enemy of the mighty emperor [sc. Theodosius] had left the domain of the dead, and appeared in the holy halls of the father [i.e. the Ennaton].' Then, it reports, the archon of Alexandria arrested Menas, and brought him to Alexandria to stand trial. The emperor then dispatched one Cosmas, 'champion of the truth', who ascertained the truth, and revealed 'the treacherous artifice' to 'the divine emperor' who, 'elevating his heart from immortal God,' ordered the conspirators punished and Menas released. ${ }^{146}$ The positive description of the emperor Phocas encourages us to place the poem before Heraclius's seizure of Alexandria in 609. ${ }^{147}$

Sophronius's poem once again attests, therefore, to reports of Theodosius's survival. As in the Constantinopolitan sources discussed above, those rumours are said to be scurrilous. But even if this is correct, it is telling, first, that contemporaries reckoned this a viable avenue for slander; second, that the 'archon' of Alexandria considered the charge credible; and third, and most important, that the emperor Phocas pursued the accusation to the point of dispatching an agent. Who was Cosmas? We know of one Cosmas active under Phocas - the demarch of the Blues in Constantinople. It is notable, then, that this same person is said to have clashed with Alexander in the earliest reign of Phocas, so that he might well

\footnotetext{
142 Theophanes, Chronographia AM 6099 (but see also AM 6101); cf. Paschal Chronicle (Dindorf 696-697) for the same executions, placing them in 605. For the plot and its sources see Olster, Politics of Usurpation 69-73.

143 Theophanes, Chronographia AM 6098 (trans. Mango and Scott, 423).

${ }^{144}$ For Sophronius in Alexandria see Booth, Crisis of Empire 44-46, 101.

${ }^{145}$ For Chalcedonians at the Ennaton see P. Booth, 'Towards the Coptic Church: The Making of the Severan Episcopate,' Millennium 14 (2017, forthcoming).

146 Sophronius, Anacreontics 21 ed. M. Gigante, Sophronii Anacreontica (Rome, 1957) 128-133, with the apparatus at 129 for the title from B (= Cod. Barb. gr. 310 iam 246, f. $59^{\mathrm{r}-\mathrm{v}}$ ). It is interesting to note that Sophronius's spiritual master John Moschus, Pratum Spirituale 127 (PG 87:3 2989D) claims to have known the aunt of a niece of Maurice - thus, it seems, not a sister of the emperor, but the sister-in-law of one of his sisters or brother-whom he calls Amma Damiana. Her first anecdote in the Pratum might suggest she was a nun on Sinai; for this association cf. below 0000.

${ }^{147}$ See also Olster, Politics of Usurpation 172-174.
} 
have made for an appropriate prosecutor of charges against Alexander's supposed crimes. ${ }^{148}$ In both Sophronius and John of Nikiu, Alexandria emerges as a focus for the emperor's enquiries, and it is not impossible that both are describing the same investigation. (Is Sophronius's archon identical with John of Nikiu's Justin?) If so, then that investigation seems to have resulted in acquittal of Menas, but the execution of Alexander.

The arrest of Menas, the execution of Alexander, and the expectations of dissident elements in the capital all suggest that the Constantinopolitan court considered rumours of Theodosius's survival credible, and that it was in active pursuit of his accomplices. There is no need to accept, then, either that those rumours were a piece of Sasanian propaganda, or that the Theodosius who accompanied the initial Persian campaigns was an impostor. As James Howard-Johnston has argued, it is improbable that Narses could have deceived both the Edessans and the Persians with his reported ruse-in particular when we consider the close connections which had existed between the two courts - and more probable that Ps.-Sebēos has seized upon some deceptive counter-narrative disseminated from Phocas' court, in a desperate effort to discredit Theodosius's claim. ${ }^{149}$ The Theodosius reported in the Khuzistan Chronicle, the Chronicle of Seert, Ps.-Sebēos, and a range of Islamic authors was therefore the eldest son of Maurice, Augustus of the Roman empire. The route via which he arrived in Persia is obscure. But it is not impossible that Ps.-Sebēos was correct in suggesting that Theodosius first fled to Edessa, either conscious of, or prompting, Narses' rebellion against Phocas. For Narses was a brilliant commander whose reputation revolved around one salient act: the restoration of the refugee Khusrau II to the throne of his father. ${ }^{150}$

Although his precise fate is uncertain, it seems improbable that Theodosius survived much longer than the capitulation of Theodosiopolis (c.608), if he had not died before at Dara (604). Nevertheless, he was to cast a long shadow over subsequent events. Several sources emphasise that Khusrau declared war in order to avenge Maurice, ${ }^{151}$ but it is doubtful that this was an unabashed 'pretext' for pursuing conquest. ${ }^{152}$ In 591 , Khusrau is said to have appealed to Maurice on the principle that the Roman emperor was bound to defend his Persian counterpart against the forces of chaos, and in the subsequent decades the two regimes had co-operated to an unprecedented extent. It would not be surprising, then, if he had greeted news of his erstwhile protector's violent usurpation with outrage, and vowed to restore a supplicant Theodosius to his throne. Indeed, even after Heraclius had deposed Phocas and sued Khusrau for peace—himself posing, according to some sources, as Maurice's avenger, ${ }^{153}$ and even as Khusrau's son ${ }^{154}$ - the shahansah refused his overtures, and, according to Ps.-Sebēos, offered a telling retort: 'That kingdom is mine, and I established T'ēodos, son of Maurice, as king. But this one has become king without our permission and offers us our own treasure as a gift. However, I shall not

\footnotetext{
${ }^{148}$ See PLRE III Cosmas 19, with Theophylact, History 8.10.11-12 (and Theophanes, Chronographia AM 6094) for the antagonism between him and Alexander. For Blues as agents of Phocas, cf. PLRE III Bonosus, with Booth, 'Shades of Blues and Greens'.

149 J. Howard-Johnston in Thomson and Howard-Johnston, The Armenian History vol. 2 197-198.

${ }^{150}$ See above p. 0000, and PLRE III Narses 10. I am indebted for this suggestion to Mr Joseph Plant, a former student at Oxford.

${ }^{151}$ Desire for vengeance: see e.g. Michael the Great, Chronicle 10.25; Chronicle to 1234 86; Eutychius of Alexandria, Annals (Alexandrian Recension) 27 (Breydy 118); Ps.-Sebēos, History 38 (Abgaryan 122).

${ }^{152}$ So Theophylact, History 8.15.7 trans. Whitby and Whitby, Theophylact 234-235: 'And so Chosroes exploited the tyranny as a pretext for war, and mobilized that world-destroying trumpet: for this became the undoing of the prosperity of Romans and Persians. For Chosroes feigned a pretence of upholding the pious memory of the emperor Maurice.' Cf. Theophanes, Chronographia 6095 (as above p. 0000).

153 See Paschal Chronicle (Dindorf 707-708); Michael the Great, Chronicle 11.1; Ps.-Sebēos, History 38 (Abgaryan 122).

${ }^{154}$ Paschal Chronicle (Dindorf 709).
} 
desist until I have taken him in my grasp. ${ }^{155}$ It is probable that at this point Theodosius was dead. But for Khusrau—as Ps.-Sebēos or his source perceived - the purpose of war was more than the simple removal of Phocas. It was rather a defence of that principle of mutual protection which had, for a fleeting moment, created a profound peace along the Romano-Persian border.

\section{The Sins of the Father}

The murder of Maurice presented a distinct conundrum for Heraclius and his court. It has sometimes been supposed that Maurice's reign was exalted in Heraclian culture and indeed, as we shall see, it offered certain precedents which could not be discarded. But an unambiguous celebration of that reign, in an attempt to accentuate the supposed crimes of Phocas, presented several obvious pitfalls: the antagonising of those who remembered the reign in more prosaic terms; the problematising of perceptions of Khusrau and his war; and the creating of an unfortunate contrast with Heraclius's own tumultuous reign. The nature of our narrative sources for the three decades after Maurice's death-for the most part products, or reflections, of Heraclian court culture-obscures contemporaneous perceptions of the crucial decades after Maurice's death. But we should remember that Heraclius was an usurper, and that his claim to the throne must have been and remained contentious, in particular once he had presided over the spectacular and unprecedented disasters of the 610s, which included, for example, his personal defeat in battle in $613 ;{ }^{156}$ the loss and sack of Jerusalem in $614 ;{ }^{157}$ and the capitulation of Alexandria in 619. ${ }^{158}$ From the perspective of the 610s and 620s, therefore, the long reign of Maurice, and its remarkable peace with the Persians, might have seemed to some a golden age.

For the first two decades of Heraclius's reign, the court's reception of Maurice's reign is more or less invisible to us. But at the end of the Last Great War, and thus concurrent with the peace at Arabissus, we first perceive a complex but concerted attempt to reshape perceptions of Maurice's rule. Theophylact Simocatta's classicising account of the empire's wars under Maurice, which we have encountered throughout our exposition, was completed in Constantinople in c.629-630, ${ }^{159}$ and was, according to its own prologue, a commission of Sergius, patriarch of Constantinople, a close collaborator of the emperor. ${ }^{160}$ It is, then, both a precious guide to the two decades 582-602 and, in addition, a frequent witness to the ideological preoccupations of the Heraclian court at a crucial moment

\footnotetext{
155 Ps.-Sebēos, History 34 (Abgaryan 113). The aorist 'I established' suggests that Theodosius was dead; pace the comment of Thomson, in id. and Howard-Johnston, The Armenian History vol. 166 n. 411: 'a future ... would make better sense.' The future does occur, however, in the parallel passage of Thomas Artsruni, History of the House of Artsrunik‘ 2.3 ed. K‘. Patkanean, Patmut’iwn Tann Artsruneats ‘ (St Petersburg, 1887) 88, who depends here on Ps.-Sebēos.

156 Ps.-Sebēos, History 34 (Abgaryan 114), with Howard-Johnston in Thomson and Howard-Johnston, The Armenian History vol. 2 206-208. Cf. Life of Theodore of Sykeon 166.

${ }^{157}$ For the sack and its sources see Stoyanov, Defenders and Enemies 11-23.

158 See R. Altheim-Stiehl, 'Wurde Alexandreia im Juni 619 n. Chr. durch die Perser erobert? Bemerkungen zur zeitlichen Bestimmung der sāsānidischen Besetzung Ägyptens unter Chosrau II. Parwēz,' Tyche 6 (1991) 3-16.

${ }^{159}$ For the date: Whitby, Emperor Maurice 39-45. Pace e.g. Olajos, Les sources de Théophylacte 11; Efthymiadis, 'A Historian and His Tragic Hero,' 180, who read references to Roman-Persian power passing to others at e.g. Theophylact, History 4.11.2-3 and 4.13.13 (cf. below p. 0000) as indicating knowledge of the Arab conquests. It is far more probable that these references mean the Avars and/or Turks (as at History 3.9.11). Cf. the comment also of Meier, 'Kaiser Phokas' 165 n. 90.

160 Theophylact, History Dialogue. For Sergius and his patronage see J. L. van Dieten, Geschichte der Patriarchen von Sergios I. bis Johannes VI. (610-715) (Amsterdam, 1972) 1-56, esp. 54-55.
} 
- that triumphant but nevertheless tragic period between the Last Great War and the first expansion of the Arabs.

On the eve of his usurpation, according to Theophylact, Maurice had become less than popular amongst the people of Constantinople. Thus he describes a significant shortage of food over the winter of 601/2, and places in the following February a riot at the Feast of Hypapante, during which stones were thrown against the emperor. ${ }^{161}$ Then, during the rebellion of the soldiers of Thrace, as Maurice attempted to arrest Germanus for treason, we are told that the Constantinopolitans turned against the emperor, denouncing him as a heretic, burning the house of the praetorian prefect Constantine, and precipitating the factions' abandonment of their posts upon the capital's walls. ${ }^{162}$ As Maurice fled the capital, 'the masses' spent the night in celebration, and denounced the fallen emperor with 'insulting chants'. ${ }^{163}$

There seems little reason to doubt that Maurice's reign was indeed unpopular in certain quarters. ${ }^{164}$ Various sources point to a controversial tightening of the fisc, and attribute this either to Tiberius's excessive largesse in the period before, ${ }^{165}$ or to Maurice's own avarice. ${ }^{166}$ But in the narrative of Theophylact, dissent against the emperor — which he is, of course, not obliged to acknowledge—is not somehow neutral. For it forms part of a wider attempt to undermine Maurice's claim to the throne, as the narrative approaches his violent death. Here, Phocas' rebellion follows upon Maurice's command that the soldiers winter north of the Danube. It is probable that this command reflected real strategic concerns, but Theophylact obfuscates this fact, attributing the command to nothing more than the emperor's parsimonious attempt to curtail the soldiers' wages. ${ }^{167}$ It at once strikes the reader, then, that for Theophylact the rebellion has a basis in legitimate political concerns. But he will go even further. As the revolt gathers pace, the lieutenant of Peter, Maurice's brother and magister militum, relates a dream in which he had received an imperial missive inscribed with the words, 'Our Lord Jesus Christ, the true God, the divine grace, the leader of the churches, accomplishes what is lacking for the advantage of everyone, and for the present promotes this master of the revolt [i.e. Phocas]. ${ }^{168}$ The qualification 'for the present' is important - but it is evident that Phocas is in fact, for now, the instrument of divine punishment. Indeed, soon after, when the soldiers set aside their grievances, and prepare ships to sail across the Danube, storms and a sudden cold rise up and reignite the rebellion. The implication is that the dangers of wintering in the north had been underlined - but coming so soon after the aforementioned dream, the reader can have little doubt that this was a further divine sign. ${ }^{169}$

161 Theophylact, History viii.4.11-12. For this riot, also described in Ps.-John of Antioch, and Theophanes, see below p. 0000.

${ }^{162}$ Theophylact, History 8.9.2-5. Cf. John of Nikiu, Chronicle 102 (Zotenberg 183), where the Constantinopolitans proclaim, 'We should have a Christian emperor in this city!'

163 Theophylact, History 8.9.7.

${ }^{164}$ See e.g. the dark warnings contained in Gregory the Great, Letters 11.4, and his celebration of Phocas' coup as above n.0000.

${ }^{165}$ See e.g. John of Ephesus, Ecclesiastical History 5.20; Chronicle to 123476.

166 John of Nikiu, Chronicle 95; History of the Patriarchs of Alexandria (Vulgate Recension) ed. B. Evetts, Patrologia Orientalis 1, 5, 10 (3 vols, Paris, 1904-1915) vol. 1 475. For the actual context of the depletion of the fisc, see P. Sarris, Economy and Society in the Age of Justinian (Cambridge, 2006) esp. 228-234.

${ }^{167}$ See Theophylact, History 8.6.10 (and cf. earlier incidents at 3.1.2, 6.7.6-7, 7.1; with the warning of Peter at 8.7.2-3), with the observations of Whitby, Emperor Maurice 165-167; Whitby and Whitby, Theophylact $219 \mathrm{n}$. 30; Efthymiadis, 'A Historian and His Tragic Hero' 182. See also Michael the Great, Chronicle 10.24 for the same explanation; but cf. John of Nikiu, Chronicle 102, where the rebels' first concern is over wages and supplies. ${ }^{168}$ Theophylact, History 8.6.5-6 trans. Whitby and Whitby, Theophylact 218.

${ }^{169}$ Theophylact, History 8.6.8. 
We need not attribute these themes to a pro-Phocan source, or to pro-Phocan propaganda, and suppose that the hapless and otherwise pro-Maurician Theophylact has somehow integrated them in error. ${ }^{170}$ It is true that the historian is sometimes inconsistent - thus in one place he calls Phocas a polluter of the purple; ${ }^{171}$ and in another he can lament the corpses of Maurice and his sons as 'calamities for the inhabited world' and 'depictions of misfortunes' ${ }^{172}$ But alongside this evident desire to excoriate Phocas, and to bemoan the beginning of his rule, the emphasis upon the popular opposition to Maurice in the capital, and upon his maltreatment of the armies of Thrace, points to a much more consistent and pervasive purpose - the development of the notion that Maurice deserved his inauspicious death.

Following his description of Maurice's flight from the rioting in the capital, Theophylact makes an unexpected turn: he now claims that Maurice 'in repentance philosophically accepted the danger' (and that Theodosius, shown his father's ring, also 'volunteered for the disaster'); that the subsequent murder of the emperor's sons was an 'advanced punishment'; and that the emperor greeted that sight with recourse to the Psalmist: 'Righteous art thou O Lord, and upright are thy judgements' (Ps. 118[119]: 137). ${ }^{173}$ There follows the aforementioned account of the nurse's failed attempt to substitute the emperor's infant son for her own, before Maurice's death is described with the words, '[T]hus the emperor became superior even to natural laws, and exchanged his life.' ${ }^{174}$ Theophylact concludes the section thus: 'It is said that, some time before his slaughter, the emperor Maurice had by letter supplicated in the more venerable churches of the inhabited world that the Lord Christ, one of the supermundane Trinity, might exact repayment for his misdeeds in this present mortal and perishable world. ${ }^{175}$ Through his atonement and stoical acceptance of his fate, Maurice therefore approaches a perverse kind of sainthood, and a contrast with Phocas is implied. But in the telling of Theophylact, the penitence of Maurice does not suffice to postpone his terrible death, nor those of all his sons.

Alongside his more famous and overt critique of Phocas, therefore, Theophylact also pursues a more complex critique of Maurice. ${ }^{176}$ To reinforce the point, in his concluding section-which culminates in the aforementioned reiteration of Theodosius's death, as the denouement of the textTheophylact also weaves a subtle condemnation of Maurice's rule, through a series of anecdotes which have sometimes been dismissed as more or less miscellaneous. ${ }^{177}$ This section contains, first, a miracle which announced the emperor's death at Alexandria before the arrival of the news, ${ }^{178}$ and then some

\footnotetext{
170 So e.g. Whitby and Whitby, Theophylact 218 n. 28; P. Schreiner, 'Der brennende Kaiser. Zur Schaffung eines positiven und eines negativen Kaiserbildes in den Legenden um Maurikios,' in T. Olajos (ed.), Byzance et ses voisins. Mélanges à la mémoire de Gyula Moravčsik (Szeged, 1994) 25-31, at 26-28. Cf. also below n. 0000.

${ }^{171}$ See the comment at Theophylact, History 8.10.1, where Phocas is called he 'who must brutally ravaged the chaste purple' (trans. Whitby and Whitby, Theophylact 225), repeating a statement in the opening Dialogue.

172 Theophylact, History 8.12.2-3 trans. Whitby and Whitby, Theophylact 225.

173 Theophylact, History 8.11.3 trans. Whitby and Whitby, Theophylact 227; cf. Theophanes, Chronographia AM 6094.

174 Theophylact, History 8.11.5-6 trans. Whitby and Whitby, Theophylact 227.

175 Theophylact, History 8.11.6 trans. Whitby and Whitby, Theophylact 227; cf. Theophanes, Chronographia AM 6094.

176 See n. 0000 above.

177 E.g. Whitby, Emperor Maurice 47-48.

178 Theophylact, History 8.13.7-15. Pace Whitby and Whitby, Theophylact 232 n. 82, but this need not be indicative of Maurice's saintliness, for when a similar miracle announces the murder in the Life of Theodore of Sykeon, the saint's monks proclaim that it was deserved, on account of the emperor's evil deeds; see Life of Theodore of Sykeon 119 (Festugière 96), with 166 for an accurate prediction of the length of Heraclius's reign, placing the text in or after 641. For portents of Maurice's death see Theophylact, History 6.111.1, 7.12.10-11; Theophanes, Chronographia AM 6093; Nicephorus Callistus, Ecclesiastical History 18.35.
} 
fleeting praise for Maurice. ${ }^{179}$ It then turns, however, to two extended, unique, and damning notices on Maurice's activities and intentions. In the first the emperor is said to have doubted and to have tested the annual miracle performed at the Church of Euphemia at Chalcedon, that is, nothing less than the venue for the Council of 451 - the clear implication, therefore, is that Maurice is an arch-heretic or even unbeliever. ${ }^{180}$ In the second he is said, in a will composed in 596/7, to have carved up the empire between his various sons - thus the implication here is that he intended, in effect, to liquidate the Roman empire. ${ }^{181}$ This will, it is claimed, was discovered under Heraclius. But one cannot help but suspect that the emperor's un-Roman testament, ${ }^{182}$ and his un-orthodox inspection of Euphemia's tomb, ${ }^{183}$ are in fact inventions of the Heraclian court. ${ }^{184}$

Through this portrait of the emperor's rule, Theophylact no doubt guards against its excessive idealisation. But it is evident that he also wants to make a point about succession. Joseph Frendo has observed how Theophylact earlier chooses to emphasise, through two passages devoted to the deaths of Maurice's predecessors, the smooth successions of both Tiberius and Maurice, and thus the legitimate transfer of power to a designated successor, rather than to an usurper. ${ }^{185}$ But his point is not simply that violent usurpation is undesirable. For these scenes-in which Tiberius, in particular, offers Maurice dire warnings about the dangers of misrule, and in which a divine voice then warns him of imminent tyranny ${ }^{186}$ —also foreshadow the failures of Maurice, and point to the latter's abrogation of the right to choose his successor. ${ }^{187}$ This specific failure of Maurice is indeed anticipated, and reinforced, through a Persian prototype set out earlier in the text. Thus through paired speeches set at the time of Bahram's rebellion, the shahanshah Hormizd serves to model the 'tyrant' whose oppressive regime has nurtured rebellion, and who has surrendered the right to continue the dynasty. ${ }^{188}$ His own nobles refuse his

${ }^{179}$ See Theophylact, History 8.13.16-17, praising Maurice’s love of learning, euergetism at Tarsus, and remission of taxes.

180 Theophylact, History 8.14.1-9. Cf. H. Grégoire, 'Sainte Euphémie et l’empereur Maurice', Le Muséon 59 (1946) 295-302, who treats the episode as historical and argues that Maurice was attempting to appease the Armenians who would serve in his subsequent Balkan campaign. On implicit criticisms of Maurice's piety, see also Efthymiadis, 'A Historian and His Tragic Hero' 182, drawing attention to the ironic contrast drawn between John the Faster and Maurice at Theophylact, History 7.6.1-5.

181 Theophylact, History 8.11.7-10.

182 Pace Feissel, 'Trois notes' 254 but I would read the reference to 'sons' in a petition of 591 from the bishops of Raetia Secunda ed. Schwartz, Concilium universale Constantinopolitanum (ACO 4.1.2) 132-135 (at 132-133: deprecamur per ... salutem dominorum filiorum vestorum, quibus perpetuum imperium deo gubernante permaneat) - and likewise the name pater imperatorum attached to him in Gregory the Great, Letters 3.61 (Norberg vol. 1 210) (593) — to mean Maurice’s descendants in general, and not that the bishops 'ne considèrent pas Théodose comme unique héritier du trône.' There is little indication that other sons of Maurice ever appeared in official propaganda, although see the report of the Patria 2.28 (Preger vol. 2 166) of statues 'of Maurice and his wife and his children' at the Chalke.

${ }^{183}$ Pace M. J. Dal Santo, 'The God-guarded empire? Scepticism towards the saints' cult in early Byzantium,' in P. Sarris et al. (eds), An Age of Saints? Power, Conflict, and Dissent in Early Medieval Christianity (Leiden, 2011) 129-49, at 135-138, who suggests that the anecdote derives from an anti-Maurician source composed under Phocas. Cf. also n. 0000 above.

${ }^{184}$ See also the statement at Theophylact, History 8.12.12 (and Theophanes, Chronographia AM 6103), that when Heraclius later reviewed his soldiers, he discovered two soldiers alone left from that which had served under Phocas.

185 Theophylact, History 1.1 (Tiberius); 3.16.4.-6, with J. D. C. Frendo, 'History and Panegyric in the Age of Heraclius: The Literary Background to the Composition of the "Histories” of Theophylact Simocatta,' Dumbaton Oaks Papers 42 (1988) 143-156, at 153-154.

186 Theophylact, History 1.2.1-2.

${ }^{187}$ On these speeches and their narrative function see esp. Efythmiadis, 'A Historian and His Tragic Hero' 174, 177-178.

${ }^{188}$ See the competing speeches at Theophylact, History 4.4.1-5.12, in which Hormizd condemns the tyranny and disorder of Bahram's rebellion, and attempts to appoint a brother of Khusrau as shahanshah (while railing against 
attempts to nominate a successor - and it is important for Theophylact that this successor is not Khusrau, whom Hormizd here denounces in the strongest terms, but a brother. Thus Hormizd mirrors and anticipates the Roman emperor Maurice, and his courtiers' subsequent slaughter of his son and preferred successor, in his presence, looks forward, in narrative terms, to the reported fate of Theodosius. ${ }^{189}$

At the same time, however, Theophylact resists two other, perhaps more obvious, parallels: that between Bahram and Phocas; and that between Khusrau and Theodosius. Both Bahram and Phocas are rebels against rulers who deserve their fates. Bahram's own subsequent failure is however twofold: first, to assume power without the consent of the Persian nobles; and, second, to refuse the rightful successor - the regal son Khusrau. ${ }^{190}$ In the first instance, we can perhaps read a prediction of Phocas, whose claim is based (in Theophylact's account) on the support of the soldiers and members of the circus factions. ${ }^{191}$ But in the second instance, the parallel between Bahram and Phocas must dissolve, for the rightful successor to Maurice would then be his son - either Theodosius or one of his brothers.

In all this, Theophylact is careful not to contradict the right of the good ruler also to pass his empire to a son, and his audience $c .630$ must have understood the message. Maurice might have failed to establish his familial line, but the emperor Heraclius matched his procreative powers, and at the time of Theophylact's text, he had had several sons, both from his first marriage to Eudocia (Heraclius Constantine), ${ }^{192}$ and through his second marriage to Martina (e.g. Heraclonas). ${ }^{193}$ Heraclius Constantine had been born on 3.v.612, ${ }^{194}$ and soon after, on 22.i.613, he was elevated to the status of co-emperor. ${ }^{195}$ In contrast to Maurice's eldest son Theodosius, Heraclius Constantine soon appeared in official regnal formulae-as contained in texts, ${ }^{196}$ documents, ${ }^{197}$ and laws ${ }^{198}$ —and on large numbers of solidi

Khusrau at 4.4.14-15); before the Persian Binodes denounces Hormizd himself as a tyrant, and denies his right to appoint a successor. On the more general role of speeches as a vehicle for Theophylact's opinions, see A. Kotłowska and Ł. Różycki, 'The Role and Place of Speeches in the Work of Theophylact,' Vox Patrum 36 (2016) 353-382.

${ }^{189}$ See Theophylact, History 4.6.2 (repeated in Theophanes, Chronographia AM 6080). The parallel is also noted in Efthymiadis, ‘A Historian and His Tragic Hero’ 176, 178-179, who also draws attention to episode of Paulinus at Theophylact, History 4.6.2, where the magician is forced to watch the execution of his son who had shared in his crimes (not mentioned in the parallel account of John of Nikiu, Chronicle 98).

190 See the letters of Hormizd and Khusrau at Theophylact, History 4.7.7-11; 4.11.5-7.

191 Theophylact, History 8.7-8.10, with Olster, Politics of Usurpation 53-59.

192 See PLRE III Constantinus 38; PmbZ Konstantinos III. 3701. On Eudocia, who died in 612, see PLRE III Eudocia quae et Fabia.

${ }^{193}$ Heraclonas (PLRE III Heraclius Constantinus; PmbZ Heraklonas 2656) was born in c.626, after the marriage to Martina in c.623 (so implied in Nicephorus, Short History 11 and Paschal Chronicle [Dindorf 714] contra Theophanes, Chronographia AM 6105, who errs in placing it in 612/3). By 630, Heraclius and Martina had also had Fabius, Theodosius, and David (PLRE III Fabius; Theodosius 44; David 8; PmbZ David 1241).

194 See Paschal Chronicle (Dindorf 702); Theophanes, Chronographia AM 6103; cf. Nicephorus, Short History 2; Ps.-Sebēos, History 34 (Abgaryan 114).

195 See Paschal Chronicle (Dindorf 703); cf. Theophanes, Chronographia AM 6104 (dating the coronation to 25.xii.612); also Nicephorus, Short History 5.

196 See Paschal Chronicle (Dindorf 704-726).

197 See P.Ital. I 21 (Ravenna, 625). Heraclius Constantine does not appear in the regnal formulae of Egyptian papyri before 630; see Bagnall and Worp, Chronological Systems 270-271; but cf. SB I 5112 (6.iii.618), where an oath formula refers to him as Augustus alongside Heraclius. For Heraclius's regnal formulae, alongside Heraclius Constantine, see also K. A. Worp, 'Regnal Formulas of the Emperor Heraclius,' Journal of Juristic Papyrology 23 (1993) 217-232; C. Zuckerman, 'La formule e datation du SB VI 8986 et son témoinage sur la succession d’Héraclius,' Journal of Juristic Papyrology 25 (1995) 187-201.

198 See the regnal formulae in Heraclius, Novels 2 (i.xi.617), 3 (24.iv.619), 4 (1.iv.629), ed. J. Konidaris, 'Die Novellen des Kaisers Herakleios,' Fontes Minores 5 (1982) 33-106, with 55-56 on the dates. 
(crowned beside his father). ${ }^{199}$ With Heraclius, therefore, we witness a far more concerted and patent effort to establish his son on the throne; and in the narrative of Theophylact, his most prominent court historian, we find an extended deliberation on the principles of filial succession, enshrined within the failed efforts of Maurice to govern his own empire well, and thus to secure his son upon the throne.

\section{The Ghost of Maurice}

Around the same time that Theophylact was completing his History, another anonymous writer working within the Constantinopolitan patriarchate completed the Paschal Chronicle, a universal chronicle stretching from creation to $c .630 .{ }^{200}$ In this Heraclian text we again encounter the claim that Theodosius died soon after his father. Thus the Chronicle states that Maurice and four sons-Tiberius, Peter, Justin, and Justinian - were arrested at St Autonomus and slain near Chalcedon, and that the praetorian prefect Constantine and Theodosius met the same fate, in unstated circumstances, at 'Diadromoi, near Acritas'. ${ }^{201}$ The narrative is here far less developed; but it agrees in essence with the facts as stated in Theophylact's account.

An alternative, and less complex, version of Theodosius's fate is encountered in the tradition of John of Antioch. Several fragments relating to the period from the end of Maurice's reign to the Heraclian revolt are embedded (in vulgarised and/or epitomised form?) in the later Excerpta of Constantine VII, and there attributed to a John of Antioch. It seems probable that these fragments once belonged to an independent text dealing with the reign of Phocas, and that by the tenth century these had somehow been attached to the authentic John of Antioch, who wrote a classicising chronicle (also known, for the most part, through the Excerpta) which ended in 518. ${ }^{202}$ Since this independent text culminated in the Heraclian revolt, and since it goes to great pains to legitimise that revolt through demonising Phocas, we can perhaps assume that it was a product both of the Heraclian period and of Heraclian patronage. ${ }^{203}$ It is striking, then, that we again encounter the insistence on Theodosius's death, in a version divested of the complications described in other Heraclian texts. For here, when Maurice

\footnotetext{
${ }^{199}$ See P. Grierson, Byzantine Coins (Berkeley, CA) 93-94, with Pl. 16 nos 274-276 for the types produced 613629.

${ }^{200}$ On the date see Whitby and Whitby, Chronicon Paschale xi, 190-191, and ibid. xxvii on the probable origins of the author within the clerical staff of Hagia Sophia, under the patriarch Sergius.

${ }^{201}$ Paschal Chronicle (Dindorf 694). On the deaths of Maurice’s sons cf. above n. 0000.

${ }^{202}$ I here follow the more cogent case of S. Mariev, Ioannis Antiocheni fragmenta quae supersunt (Berlin, 2008) contra Roberto, Ioannis Antiocheni fragmenta, the latter nevertheless including within his useful edition the fragments from the Excerpta concerning Maurice, Phocas, and Heraclius (from which I cite above and below). Roberto's fundamental argument is that these derive from an epitome of John's work which has removed the classicising veneer, where elsewhere in the Excerpta it has been retained. This cannot be discounted, but besides the stylistic and linguistic dissonance between the earlier and later material, it is problematic for Roberto's position that Johannine fragments covering the period from Justin I to Tiberius are almost non-existent in the extant Excerpta, which encourages us again to think of separate works. For the various salvos in this debate see e.g. S. Mariev, 'Neues zur “Johannischen Frage”?' Byzantinische Zeitschrift 99 (2006) U.535-549; U. Roberto, 'Research Prospects on John of Antioch, Notes on the Edition by S. Mariev,' Jahrbuch der österreichischen Byzantinistik 60 (2010) 115-128; S. Mariev, 'John of Antioch Reloaded: A Tutorial,' in M. Meier et al. (eds), Die Weltchronik des Johannes Malalas: Autor - Werk - Überlieferung (Stuttgart, 2016) 253-266. For the problems of both positions see P. van Nuffelen, 'John of Antioch, Inflated or Deflated. Or: How (Not) to Collect Fragments of Early Byzantine Historians,' Byzantion 82 (2012) 437-450.

${ }^{203}$ On Phocas see U. Roberto, 'The Circus Factions and the Death of the Tyrant: John of Antioch on the Fate of the Emperor Phocas,' in F. Daim and J. Drauschke (eds), Byzanz - das Römerreich im Mittelalter (3 vols, Mainz, 2010) 55-77, although his attempt to make such passages integral to a wider theme, as witnessed in the earlier Johannine fragments, is not convincing.
} 
and his children flee the palace upon Phocas' coronation, Theodosius is instead captured and slain. ${ }^{204}$ There is no suggestion that he died later than his father.

Although Ps.-John of Antioch's account seems to be independent of that of Theophylact, it nevertheless reinforces several more of the latter's themes. Ps.-John also reports on a riot during the Hypapante in 602-so that he too has chosen to underscore popular opposition to the emperor-but he adds that the rioters then found a bald man who resembled Maurice, dressed him with a crown of garlic, seated him on an ass, and mocked him with an insulting chant. ${ }^{205}$ Another fragment partakes of another familiar theme - that a penitent Maurice invited his own fate. Set on the eve of the Thracian rebellion, this anecdote reports a revelation in which Maurice saw himself standing on the purple marble before the Chalke gate, from a which a voice asked him, 'How do you want that I repay you? Now or in the future?' Maurice then answered, 'Now', and the voice ordered for him to be given to the soldier Phocas. ${ }^{206}$ Both anecdotes appear, in more elaborate form, in the later Chronographia of Theophanes, who places the dream of Maurice soon after the dispatch of that letter, alleged in Theophylact, in which the penitent emperor supplicated the churches to intercede for his sins. ${ }^{207}$ Theophanes, therefore, has supplemented his use of Theophylact through recourse either to a fuller version of Ps.-John's Chronicle than that represented in our fragments, or to an intermediate source. ${ }^{208}$ Thus when we find Theophanes interpolating within the narrative of Theophylact a much clearer sense of Maurice's sin-alleging that he ordered Comentiolus to betray the armies of Thrace, and that he later refused to ransom Roman solders from the Avars-it is possible that the theme in fact derives from Ps.-John, where it once provided the context for the emperor's dream. ${ }^{209}$

The thematic correlation between Theophylact and Ps.-John suggests an effort, coordinated at the Heraclian court, to frame the reign of Maurice in particular terms. Indeed within the Greek tradition, this effort seems to have been a remarkable success. In the corpus of Anastasius of Sinai we encounter three vignettes connected to Maurice's death. The first occurs in the Questions and Answers (c.700), where Anastasius narrates in passing, as an example of those who swap a bitter death for salvation, that aforementioned dream of Maurice-also present in Ps.-John, and thence in Theophanes-in which God commands that he be delivered to Phocas. ${ }^{210}$ The second and third occur in the two collections of Anastasius's Tales (c.670-c.690). ${ }^{211}$ In the first collection, an ascetic tells of a secretive monk on Sinai

\footnotetext{
204 Ps.-John of Antioch, Chronicle 318 (= De ins. 108).

205 Ps.-John of Antioch, Chronicle 317 (= De ins. 107) (Roberto 546).

206 Ps.-John of Antioch, Chronicle 318 (= De ins. 108) (Roberto 548).

${ }^{207}$ Dream: Theophanes, Chronographia AM 6094. Riot: ibid. AM 6093.

${ }^{208}$ On Theophanes' use of Ps.-John see Mango and Scott, Chronicle lxxxi; Roberto, 'Death of the Tyrant' 70-71. With these authors I see no reason to accept the complex position of Whitby, 'Theophanes' Chronicle Source' 338-340 (cf. the stemma at 344 n. 141) that similarities between Theophanes and Ps.-John are to be explained through the latter's dependence on a Constantinopolitan chronicle which also served (along with a posited Life of Maurice - cf. below p. 0000) as basis for one of Theophanes' supposed sources, the Great Chronographer. Nevertheless a full treatment of the transmission and reception of Ps.-John's Chronicle in the later chronographic tradition is much needed.

${ }^{209}$ See the claim that Maurice ordered Comentiolus to betray the Roman army (Chronographia AM 6092 [de Boor 279]), and that he later refused to ransom some Romans from the Avar khagan (Chronographia AM 6092 [de Boor 279-280]).

210 Anastasius Sinaita, Questions and Answers 30 ed. M. Richard and J. A. Munitiz, Anastasii Sinaitae Quaestiones et Responsiones, CCSG 59 (Turnhout, 2006) 80-81: 'For when the emperor Maurice asked God to be recompensed in this world for the sins which he had himself committed, he saw in a dream a certain, most glorious emperor ordering that he be handed over to the soldier Phocas - and so it happened.'

${ }^{211}$ I here follow B. Flusin, 'Démons et Sarrasins: L'auteur et le propos des Diêgêmata stêriktika d'Anastase le Sinaïte,' Travaux et Mémoires 11 (1991) 380-409, esp. 393-394, and A. Binggeli, Anastase le Sinaïte: Récits sur le Sinaï et Récits utiles à l'âme: édition, traduction, commentaire, unpublished PhD dissertation, Paris IV (2 vols,
} 
whom, after his death, certain people claimed him to be 'the son of Maurice whom his nurse saved from the massacre at the Hippodrome by exchanging her own son', and who had become an ascetic in order to atone for the nurse's child. ${ }^{212}$ Then, in the second collection, Anastasius narrates a remarkable and otherwise unique anecdote which imagines the emperors' entrance into heaven as a procession into an imperial palace. In this 'Leontius the Neapolitan' recounts how his spiritual master had been a friend of Maurice, and how when the emperor died, the elder called upon God to reveal to him his current condition. One night, he saw himself in 'a most glorious place, like an imperial palace,' and heard the voice of an emperor, concealed within the palace, summoning by name the Roman emperors 'who had ruled piously'. First came Constantine, bearing the True Cross along with Helena. Then came a procession of the (unnamed) 'worthy' emperors, stretching to Tiberius. At this, however, the voice became lower and more strained, and beckoned Maurice enter. Thus the latter entered along with his wife and children, and seeing the elder 'before the doors', the emperor ordered his family to do obeisance to him, 'For because of him, the alone good and philanthropic master has opened up to us.' 213 The implication therefore, is that the emperor had done something to exclude him from heaven - but that he is able to enter through the intercession of the elder.

It is possible that after penning this tale, Anastasius composed another version, contained in the so-called De dignitate sacerdotali, the attribution of which is disputed. ${ }^{214}$ If authentic, it is notable that here Anastasius introduced some crucial changes. For example, the raconteur Leontius is now specified as the future bishop of Neapolis (i.e. the famous hagiographer), and is described as then resident as a monk in the East; the palace is instead a massive church, and the voice is that of Christ from the altar; and the scene is modelled on the emperor's procession into Hagia Sophia (the 'doors' are here 'the imperial doors'). But for our purposes, the most remarkable contrast is a far more patent emphasis upon Maurice's sins. In the earlier version, the reason for the elder's intercession is not stated. But here that intercession happens before the emperor's death, '[w]hen through the operation of the devil the same

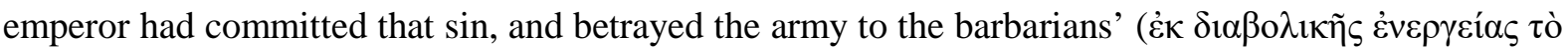

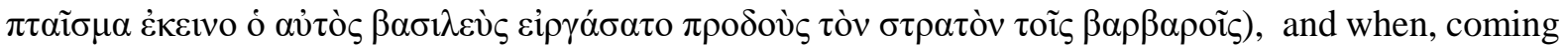
to a sudden realisation and regret, he then wrote to the elder and summoned him 'to strenuously petition God to grant to him the soul of Maurice, and to forgive him his sin.' Here, then, we encounter the

2001) vol. 2 331-340, who identify the authors of the two collections and suggest that both were produced in the period c.670-c.690. Note, however, that K.-H. Uthemann, Anastasios Sinaites: Byzantinisches Christentum in den ersten Jahrzehnten unter arabischer Herrschaft (2 vols, Berlin, 2015) vol. 1 367-463 has since restated the differentiation of the two authors, and attributed the first collection to a different Anastasius writing in the period before 629. However his various arguments against a date in the Arab period are in each case the least economical interpretation of the evidence, and his identification of the first collection's higoumen John with the higoumen John who received a letter of Gregory the Great in 600 (and with John Climacus), presents more problems than a simple acknowledgement of an earlier and later John.

${ }^{212}$ Anastasius of Sinai, Tales 1.39 ed. A. Binggeli, Anastase le Sinaïte: Récits sur le Sinaï et Récits utiles à l'âme: édition, traduction, commentaire, unpublished PhD dissertation, Paris IV (2 vols, 2001) vol. 1214 (I cite this edition as the most accessible and up-to-date version, but cf. the criticisms of Uthemann, Anastasios Sinaites esp. 463-582). The same anecdote appears in Eutychius of Alexandria, Annals (Alexandrian Recension) 27 (Breydy 118), who probably here depends on Anastasius; see Binggeli, Anastase le Sinaïte vol. 2524.

${ }^{213}$ Anastasius of Sinai, Tales 2.24 (Binggeli vol. 1255 ).

${ }^{214}$ In Q42 (De non iucando) in the so-called 'Collection B' of Anastasius of Sinai, Questions and Answers, published as Appendix 18.6-7 in Richard and Munitiz, Quaestiones and Responsiones 198-200. Q39-42 are often transmitted in long and short recensions as the separate treatise De dignitate sacerdotali, of which there is a partial edition in F. Nau, 'Le text grec de récits utile à l'âme d'Anastase (le Sinaïte),' Oriens Christianus (1903) 56-90, at 79-84, nos 54-56. Richard and Munitiz, and before M. Richard, 'Les textes hagiographiques du codex Athos Philothéou 52,' Analecta Bollandiana 93 (1975) 147-156 doubt, without much justification, the authenticity of the treatise, as now does Uthemann, Anastasios Sinaites vol. 2 788-790; contra Binggeli, Anastase le Sinaïte vol. 1 146-152, vol. 2 411-415, who argues that the De dignitate sacerdotali is authentic and dates it to the 690s. 
tradition of Maurice's letter to the churches (as contained in Theophylact, and thence in Theophanes) combined with the tradition of his betrayal of the armies in the Balkans (as contained in Theophanes, perhaps via Ps.-John of Antioch).

Maurice appears in two further places in Anastasius's corpus. Elsewhere in the Tales, he relates the tale of magician, Mesites, who lived at Constantinople under Maurice; ${ }^{215}$ and in his Sixth Homily on the Psalms, he recounts an anecdote about a brigand and murderer in Thrace whom 'the pious Maurice' brought to heel, and who then repented. ${ }^{216}$ It has therefore been suggested that he has access to an independent source on Maurice, and even that the reign of Maurice-in contrast to that of the demagogue Phocas, ${ }^{217}$ or the heretic Heraclius ${ }^{218}$ _represents for Anastasius 'un âge d'or de la romanité. ${ }^{219}$ The amorphous and discordant nature of Anastasius's materials on Maurice make it improbable that all derive from a single source; but it is nevertheless evident that he is conscious of a cluster of Constantinopolitan traditions (the divine dream; the sins and penitence of Maurice; the ruse of the nurse) around Maurice's death. At the same time however, if the latter's reign was indeed perceived as a lost golden age, then Anastasius cannot have understood either the origins or meaning of his anecdotes. For those two which relate visions connected to Maurice's death-the procession of emperors into heaven; and God's deliverance of the emperor to Phocas-are both based in the traditions of Maurice's sin and subsequent penitence, and serve to reinforce the rhetoric of the Heraclian court: that is, that Maurice had surrendered his right to rule, and that in murdering him Phocas, for all his subsequent failings, was in effect the executor of both natural and divine justice.

The interpretations of Maurice's death cultivated under Heraclius—and manifested in particular in Theophylact, the Paschal Chronicle, and Ps.-John of Antioch-are also evident in another remarkable text. In 1902 François Nau edited, from a single Syriac manuscript of East Syrian provenance, a short treatise or extract devoted to Maurice's death. The text commences with a brief account of the emperor's life-which he divides between the business of empire and the practice of prayer-but then moves to his death. In old age the emperor petitions God to punish him in this life for his sins, and not to deprive him of the highest rank in heaven. An angel then appears and reveals that his sin has prevented him from attaining perfection, but that he has nevertheless attained something of the lot of the saints, and that if he wants to prolong both his rule and the lives of his children, then he will cease from his petition. If, however, he still desires punishment in the here-and-now, and the subsequent attainment of perfection, he will lose the empire and his eight children will be massacred. Maurice assents to the punishment. At this, Phocas launches his rebellion, proclaiming, to the apparent acceptance of all Romans, the emperor's incompetence and failure to maintain the empire. Maurice is arrested, and seven of his children are murdered in front of him. The emperor, however, then reveals that an eighth is living with his nurse who, before Phocas' agents arrive, substitutes her own son in the

\footnotetext{
${ }^{215}$ Anastasius of Sinai, Tales 2.18. For the same cf. again Q42 in 'Collection B', published as Appendix 18.1012 in Richard and Munitiz, Quaestiones and Responsiones 201-202. For the same magician (placed under Justinian and called, in Ethiopic, Māsidis) cf. John of Nikiu, Chronicle 90 (Zotenberg 155-156). G. Fiaccadori, 'Māsidis (Giovanni di Nikio, Chron. XC 54 - 60),' in id. (ed.), In partibus Clius: Scritti in onore di Giovanni Pugliese Carratelli (Napoli, 2006) 113-137, argues that Māsidis indicates Mazdikites, but he does not acknowledge Anastasius's evidence. See also BHG 801b.

${ }^{216}$ Anatasius of Sinai, Sixth Homily on the Psalms, PG 1116-1144, at 1140AB. For the same tale cf. Eutychius of Alexandria, Annals (Alexandrian Recension) 26 (Breydy 113-115); who must depend here on Anastasius's sermon (Binggeli, Anastate le Sinaïte vol. 1 524).

${ }^{217}$ Cf. Anastasius of Sinai, Questions and Answers 65.

218 See e.g. Anastasius of Sinai, Against the Monotheletes 1.18-83 ed. K.-H. Uthemann in Sermones duo in constitutionem hominis secundum imaginem Dei, CCSG 12 (Turnhout, 1985) 35-83, at 56-59.

${ }^{219}$ Bingelli, Anastate le Sinaïte vol. 2525.
} 
infant's stead. When those agents return with the child, however, Maurice discloses the nurse's deception, and the true son is fetched and also murdered. At last, Maurice, his hands bound behind his back, is placed upon a boat, which is set upon the sea and set ablaze. The fire burns through his bonds, and he ends his life with his hands raised to God, giving thinks that he has received such grace. ${ }^{220}$

It is reasonable to suppose that the text had its origin at the Sasanian court, as Khusrau sought to transform the murdered emperor into a saint, and thus to validate his claim to act as Maurice's avenger. ${ }^{221}$ But its purpose, perhaps, is more pointed. It is true that the introduction and conclusion of the text presents us with Maurice as ascetic and martyr, in a manner unparalleled in other texts, and that here the emperor's murder, alongside his children, achieves less the expiation of some terrible sin than promotion to a higher form of sainthood. But the core of the text is nevertheless comprised of motifs familiar from Greek texts: the divine revelation of death and its stoical acceptance; the intimation of some failure of governance, and the Romans' consent to their emperor's fate; and the slaughter of all the emperor's sons, including the infant whom the nurse had attempted to protect. It is tempting, therefore, to regard the text as a deliberate reworking of, and response to, ideas emanating from the Constantinopolitan court, which sought not so much to celebrate as to delegitimise Maurice's rule. ${ }^{222}$ Can we be more precise? The absence of Theodosius is perhaps suggestive of a date after his death (c.604-c.608); and it is difficult to imagine that the text remained relevant long after the death of Khusrau (628). It is possible, therefore, that it originated in the reign of Heraclius, when the RomanoPersian war was still ongoing, and when each side was contesting the meaning of Maurice's death. ${ }^{223}$ If this is correct, then it suggests that some form of the Roman version was circulating long before its classic articulation in the narrative of Theophylact.

Long ago Michael Whitby posited the existence of an independent Greek Life of Maurice, 'a collection of hagiographical stories' which served as a source for Theophylact (and also reflected in our East Syrian text). ${ }^{224}$ Although the existence of a formal written 'Life' is difficult to establish, ${ }^{225}$ the repetition and concatenation of the same themes (the failure of Maurice to govern; the divine dream; the penitence and acceptance of death; the nurse's ruse; and the slaughter of all the sons) in otherwise independent but more-or-less contemporaneous sources (Theophylact, Ps.-John of Antioch, the Syriac Life) is indeed suggestive of a common point of origin, even if the nature of the shared source or sources, whether written or oral, and their transmission to, and reception by, different authors must remain

\footnotetext{
${ }^{220}$ F. Nau, 'Les légendes syriaques d'Aaron de Saroug, de Maxime et Domèce, d'Abraham, maître de Barsoma, et de l'Empereur Maurice,' Patrologia Orientalis 2, at 773-778 with 767 on the ms. (Paris syr. 309 ff. 313-317). For the positive image of Maurice see also Agapius, Universal History (Vasiliev vol. 3 439). Note that Eutychius of Alexandria, Annals (Alexandrian Recension) 27 (Breydy 118) has a different account of Maurice's death, at the hands of an aggrieved servant whom Phocas had paid off.

${ }^{221}$ On the sanctification of Maurice in this text see e.g. J. Wortley, 'The Legend of the Emperor Maurice,' in Actes du Congrès International d'Études Byzantines (Athens, 1980) 382-391, at 387-389; Whitby, 'Theophanes' Chronicle Source' 340; Schreiner, 'Der brennende Kaiser’ 30-31.

${ }^{222}$ Such a project is perhaps also reflected in the Chronicle of Seert, which is positive about Maurice $(55,70)$, but then states the following after his murder (78, ed. and trans. Scher 517-518): 'Maurice saw in a dream a richly dressed man standing before him, who told him to hold out his hands. Maurice held them out and the man wrote on them four letters in Greek which meant, "God orders that Phocas reign in the place of Maurice." He had resigned himself to the will of God and had demanded in his prayers that he be punished in this world.'

${ }^{223}$ Whitby, Emperor Maurice 3 dates it to 'about a decade after his death in 602', without comment.

${ }^{224}$ See Whitby, 'Theophanes' Chronicle Source’ 318-319, 335-336; and Whitby, Emperor Maurice 105-109.

${ }^{225} \mathrm{~A}$ considerable desideratum in this respect is a full treatment of the interrelations, and possible shared sources (including Ps.-John of Antioch), of the treatment of Maurice's reign in the later chronographers (Theophanes, Georgius Monachus, Symeon the Logothete, Cedrenus, Zonaras, Manasses, etc.). For an initial exploration see Wortley, ‘The Legend’ 383-387. Cf. also above n. 0000.
} 
unclear. ${ }^{226}$ Whitby suggests that the most obvious point of origin for this tradition is the court of Heraclius soon after 610, when the emperor was posing as Maurice's avenger before Khusrau, and when the portrait of a Maurice as a penitent sinner would have satisfied that emperor's surviving critics while also highlighting his harsh treatment at the hands of Phocas. ${ }^{227}$ This is indeed possible, but there is no reason that the image of Maurice as a tragic hero (which is, as we have seen, far from hagiographic) could not also have been conducive to Phocas, in particular since all the dependents of our posited tradition on Maurice's death suggest that the murder was, in some sense, legitimate. ${ }^{228}$ It is therefore possible that the same tradition in fact originated at the court of Phocas, who could thus present himself not as the callous murderer of an emperor who was beloved, successful, and unwilling, but as the executor of God's sentence upon one who was hated, failing, and resigned.

\section{$\underline{\text { Conclusion }}$}

When the Persians first reached Chalcedon in 615, the emperor Heraclius is said to have sailed out to a summit, conducted from his boat, with the Persian general Shahin. There, the latter addressed to the emperor a speech in which he emphasised his desire to resurrect that ancient concord between the two great empires, which was conducive to an ordered, contented life. 'This concord,' he proclaims, 'should be as profound as our empires are great; for we know that no other state will ever appear to rival these our empires.' However, if Heraclius pursues conflict, the result will be mutual destruction, and 'our states will be reduced to a wretched and miserable condition. ${ }^{229}$

The report of this remarkable speech is not, of course, reliable. It derives from a source composed in the reign of Constans II, and with clear knowledge of the Arab conquests. ${ }^{230}$ But the principles which it expresses had deep roots within Romano-Persian diplomatic discourse. ${ }^{231}$ According to Theophylact, when the refugee Khusrau had in 591 appealed to Maurice in a letter, he pointed to the same principle, that is, that the two empires preside over the civilised world and, together, regulate 'the disobedient and bellicose tribes'. ${ }^{232}$ 'It is then fitting,' Khusrau continued, 'for your peaceful providence to give a saving hand to a kingdom that is being ravage and coerced by tyrants, to support a power that is on the point of dissolution, to establish in the Roman state the cause of salvation, as if it were a universal trophy, and to proclaim yourselves the founders, saviours, and physicians of the Persian state. ${ }^{233}$ Soon after, Khusrau dispatched ambassadors to Maurice who again insisted on the need for two powers to regulate the world, pointing to the failure of Alexander the Great to establish a universal

${ }^{226}$ Cf. Olajos, Théophylacte 149 n. 668, who follows Wortley, 'The Legend' 382-383, in thinking that the 'hagiographic' traditions around Maurice was still in formation c.630, and that Theophylact knew them through 'une connaissance orale'. Frendo, 'History and Panegyric', 155-156, suggests that the 'hagiographic Maurice legend' in part depends on the lost Life of John the Faster; but cf. M. Whitby, 'Greek Historical Writing after Procopius: Variety and Vitality,' in A. Cameron and L. Conrad, The Byzantine and Early Islamic Near East (Princeton, NJ, 1992) 25-80, at 51 n. 111.

${ }^{227}$ Whitby, 'Theophanes’ Chronicle Source’ 318; Emperor Maurice 108.

${ }^{228}$ As suggested in F. H. Tinnefeld, Kategorien der Kaiserkritik (Munich, 1971) 54-57, whose opinion Whitby, 'Theophanes' Chronicle Source' 336 n. 115 argues against, on the basis that the Life sanctified Maurice.

${ }^{229}$ Nicephorus, Short History 6 (trans. Mango 45-47).

${ }^{230}$ See C. Zuckerman, 'Heraclius and the return of the Holy Cross,' id. (ed.), Constructing the Seventh Century, Travaux et Mémoires 17 (Paris, 2013) 197-218, at 207; C. Boudignon, 'Is the patriarch Pyrrhos (638-641 and 654) the author of the first part of Nikephoros' Short history (ch. 1-32)?’ (forthcoming).

${ }^{231}$ See esp. M. Canepa, The Two Eyes of the Earth: Art and Ritual of Kingship between Rome and Sasanian Iran (Berkeley, CA, 2009) esp. 124-127.

232 Theophylact, History 4.11.3 trans. Whitby and Whitby, Theophlyact 117. On the 'tribes' cf. above n. 0000.

233 Theophylact, History 4.11.8 trans. Whitby and Whitby, Theophlyact 118. 
empire, and warning of the dangers to the Romans if another 'tribe' should take the Persian place. ${ }^{234}$ We should not see here, as in Nicephorus, references to the Arabs, however prescient the sentiment. ${ }^{235}$ For Theophylact wrote amidst the wreckage of a war in which a Persian alliance with the Avars, and a Roman alliance with the Turks, had almost spelled the end for both empires. ${ }^{236}$

When Heraclius and Shahrbaraz met at Maurice's birth place in 629, the obscure choice of venue was no doubt meant to resonate with the same principles of political co-operation. From the perspective of the Heraclian court, the later reign of Maurice had represented a highpoint in relations between the two great powers, a period of profound peace which the two great generals would now restore. The rendezvous at Arabissus, then, was suffused with memories of Maurice and of Khusrau in 591. Heraclius, for his part, acted out the role of Maurice, the Roman emperor whose armies would soon restore a Persian claimant to Ctesiphon; while Shahrbaraz assumed the role of Khusrau, restoring Christian relics to his Roman counterpart, and perhaps even flirting with the imminent conversion of the Persian state - for the son and heir who restored those relics, the new patrikios Niketas, was a Christian. ${ }^{237}$ At the same time, the bonds between the two families were confirmed through intermarriage—as had been the case, according to Sasanian tradition, in 591—when Heraclius betrothed his infant son to Nike, the daughter of Shahrbaraz. ${ }^{238}$ As if to cap the resonances with Maurice's reign which pervaded the conference, that same son bore an arresting (and not unironic) name Theodosius. ${ }^{239}$

In Heraclian literature, the emperor Maurice was a complex and equivocal figure. For various reasons, there was little desire to eulogise his reign in absolute terms, and Heraclian authors instead cultivated the intimation that the emperor had deserved his punishment. According to this narrative, through his failure to govern —as manifested, in particular, at the end of his reign—Maurice had undone his two great achievements: first, the period of profound peace with the Persians, and the remarkable co-operation with Ctesiphon; and, second, the resuscitation of the principle and modes of Roman filial succession, in anticipation of Theodosius's ascent to the throne. It seems quite evident that Theodosius did in fact survive his father's murder, as Phocas suspected and as texts produced within the sphere of Sasanian influence also alleged. Thus when Heraclius launched his coup from Carthage, it is possible that he was unsure of the emperor's fate, in particular if the latter was still alive at the siege of Theodosiopolis (c.608). He might even have posed as his defender, ${ }^{240}$ for the gold and silver coinage of Carthage described above suggests that Theodosius had been held in special affection there, and during his revolt it is notable that the solidi of the Carthaginian and Cypriote mints did not present Heraclius as emperor, but as consul. ${ }^{241}$ Nevertheless, in the context of his subsequent rule, when Theodosius was dead but rumours no doubt persisted, there could be no suggestion that the emperor

\footnotetext{
234 See Theophylact, History 4.13.4-26. On these letters and their authenticity see A. Ciancaglini, 'Le "lettere persiane” nelle Storie di Teofilatto Simocatta,' in La Persia e Bisaznio (Rome, 2004) 639-649.

${ }^{235}$ See above n. 0000 .

${ }^{236}$ Note that Theophylact gives little sense that the principle of mutual protection was debated. Cf. the evident dissent at Khusrau's appeal evident in other texts (above n. 0000). See also the comment of Whitby and Whitby, Theophylact $120 \mathrm{nn}$. 47-48, on the obfuscation of a long period of debate.

237 On Niketas see Mango, 'Deux études’ 105-117.

238 See above p. 0000.

239 See above p. 0000.

240 This might explain the association made in Ps.-Sebēos' History between the survival of Theodosius and the factional violence which accompanied the Heraclian revolt, in which the Greens (Maurice's colour) supported Heraclius; see above nn. 0000. I owe this suggestion to a former tutee at Oxford, Mr Joseph Plant.

${ }^{241}$ See P. Grierson, 'The Consular Coinage of “Heraclius” and the Revolt against Phocas of 608-10,' Numismatic Chronicle 6.10 (1950) 71-93, preferring to think, however, that Heraclius's father alone had assumed the title of consul (even though in the less senior position on the coins).
} 
had denied the rightful claimant to the throne. Hence the repeated insistence on Theodosius's death; hence the notion that Theodosius was not full heir to the empire in his father's will; and hence also the parallel suggestion, that Maurice had even so (like Hormizd before him) abrogated his right to designate a successor.

It is above all in the narrative of Theophylact that this complex scheme finds its finest and most elaborate expression. Older approaches to Theophylact did much to illuminate his sources for, and reporting of, events, but were little impressed with his skills as a researcher or writer. ${ }^{242}$ In some more recent scholarship, however, appreciations of the text as literature, rather than reportage, have produced more positive perspectives - thus the frequent speeches, for example, have been seen as crucial vehicles for a range of sophisticated narratological techniques; ${ }^{243}$ while the character of Maurice has been framed not as simple saint, but as a multifaceted tragic hero. ${ }^{244}$ This revisionism has done much to rehabilitate the reputation of Theophylact, and to advance the appreciation of the text on its own terms. But in uncovering these complexities, it is crucial that we not lose sight of the particular context in which he wrote - as a dependant of the Heraclian regime, and in that remarkable period in which the Roman and Persian eminences once again returned to rapprochement and co-operation. Theophylact's interest in the reign of Maurice was not that of a mere antiquarian, but nor was it that of a simple moralist. For in his hands, and in those of his contemporaries, the rule of Maurice became a vehicle for specific reflections on the reign of Heraclius, and on the interconnected themes of pious rulership, international politics, and dynastic power. Those reflections are testament to a short, tragic moment at the apex of the Last Great War, a moment in which contemporaries could, for the last time, express some confidence in the immemorial world order, and in the perpetuation of two ancient empires which in fact stood on the brink of oblivion.

\footnotetext{
${ }^{242}$ See esp. the criticisms of Whitby, Emperor Maurice 311-354; more recently W. Treadgold, The Early Byzantine Historians (New York, NY, 2007) 337-340, is also unsympathetic.

${ }^{243}$ See e.g. J. D. C. Frendo, 'Three Authors in Search of a Reader: An Approach to the Analysis of Direct Discourse in Procopius, Agathias, and Theophylact Simocatta,' in C. Sode and S. A. Takács, Novum Millennium: Studies in Byzantine History and Culture Presented to Paul Speck (Aldershot, 2001) 123-136.

${ }^{244}$ See Efthymiadis, 'A Historian and His Tragic Hero.'
} 